Potential of industrial by-products and wastes from the Iberian Peninsula as carbon sources for sulphate reducing bacteria

Short Title: Potential of industrial by-products and wastes as carbon sources for SRB

J.D. Carlier ${ }^{1}$, L.M. Alexandre ${ }^{1}$, A.T. Luís ${ }^{1}$, M.C. Costa ${ }^{1 *}$

1 - CCMAR, University of Algarve, Campus de Gambelas, 8005-139 Faro, Portugal.

Phone number: +351289800900, ext. 7634; e-mail: mcorada@ualg.pt

*Corresponding author 
Short Title: Potential of industrial by-products and wastes as carbon sources for SRB

\title{
Potential of industrial by-products and wastes from the Iberian Peninsula as carbon sources for sulphate reducing bacteria
}

\begin{abstract}
Industrial by-products and wastes from Portugal and Spain were tested for the first time as carbon sources/electron donors for sulphate reducing bacteria. Cultures in mineral medium supplemented with the tested substrates were monitored and sulphate reduction efficiency is discussed in light of substrates compositions, dosages and corresponding chemical oxygen demand/[ $\left.\mathrm{SO}_{4}{ }^{2-}\right]$ ratios. The use of doses targeting a ratio of 1.5 was a good strategy to optimize sulphate reduction activity. As expected, this activity was faster for substrates that have in their composition simple compounds such as low chain alcohols and organic acids and/or compounds that can be rapidly degraded such as sugars, though it also occurred in a longer-term perspective with substrates composed mainly of slowly degradable compounds such as cellulose and lignin. Among eighteen tested substrates, six supported high sulphate reduction efficiency during incubation periods varying between two and four weeks (sugared water from a factory of candies, beetroot molasses, olive mill wastewaters not decanted and decanted, orange molasses without conservative and municipal wastewater from Mina de São Domingos, Portugal), while eight substrates sustained moderate sulphate reduction efficiency during periods from three to seven weeks (water from washing beetroots, Carbocal®, orange molasses with conservative, liquor extracted from orange peels, orange peel fragments, water from washing industrial equipments used to produce orange juice, pine nut shells and pine cone fragments). Nevertheless, after four months of incubation, total sulphate removal was observed with three of the solid substrates tested (orange peels, pine nut shells and pine nut cones).
\end{abstract}

\section{Keywords}

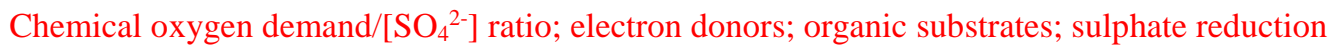

\section{Introduction}

Sulphate reducing bacteria (SRB) comprises a diverse group of microorganisms with the ability to obtain energy through anaerobic respiration by dissimilatory sulphate reduction, in which sulphate is the oxidising agent (electron acceptor) for the oxidation of certain compounds (electron donors), resulting in the release of sulphide. The resistance of SRB to extreme conditions and the fact that sulphide reacts with several metals forming precipitates have made these microorganisms known for their potential in bioprocesses to treat waters contaminated with metals and sulphate, such as acid mine drainage (AMD) (e.g. Costa et al. 2017; Dev et al. 2017; Miran et al. 2017; Muhammad et al. 2017). However, these waters are usually poor in compounds used by SRB as carbon sources and electron donors to obtain energy, thus 
their biological treatment requires addition of such products (e.g. Lefticariu et al. 2015; Vasquez et al. 2016). Therefore, the efficiency and economic viability of a SRB based bioremediation process depends largely on the substrate used as carbon source and/or electron donors to feed bioreactors. The substrate must have compounds that can be directly used in the anaerobic respiration of SRB and/or others that despite not being immediately viable can be relatively rapidly decomposed into suitable ones.

Organic compounds resulting from fermentation processes, such as ethanol and methanol, as well as others such as volatile fatty acids (formic, acetic, propionic, butyric) and short chain fatty acids (lactic, pyruvic, malic) or just hydrogen or monoxide carbon, can be used as carbon sources and/or electron donors by SRB (e.g. Liamleam and Annachatre 2007; Parshina et al. 2010). However, the high costs associated to purchasing and handling such compounds in pure forms hamper their use in large scale operating treatment processes. The chemical reactions involved in the metabolic transformation of compounds that can be used as energy sources by SRB have been described for example by Cao et al. (2012) and benefits and drawbacks for known possible electron donors in biological wastewater treatment processes based on sulphate reduction were reviewed by Hao et al. (2014).

Over the years several low-cost industrial by-products rich in carbon compounds have been successfully tested as sources of electron donors for SRB, as for example sugar cane molasses and bagasse from the sugar processing industry (e.g. Michailides et al. 2015; Hussain and Qazi 2016). On the other hand, the use of zero-cost wastes to sustain SRB bioremediation processes is even more interesting from the economic point of view. Moreover, the use of wastes to treat waters contaminated with metals is also particularly interesting from an environmental point of view since it may constitute an integrated system to treat simultaneously different pollutants. Different types of wastes rich in carbon compounds, such as for example winery wastes, animal manure and grass cuttings (Martins et al. 2009; Zhang and Wang 2014; Mulopo 2016), have already been reported as valuable carbon sources/electron donors for SRB. A different approach is the use of SRB for co-treatment of different wastes. According to Li et al. 2017, AMD was used as a source of sulphate to strengthen the anaerobic treatment of landfill leachate. The results obtained showed high removal efficiency of chemical oxygen demand (COD), methane production and also heavy metals removal.

The Iberian Pyrite Belt (IPB), located in the south-west of the Iberian Peninsula (Figure 1), is one of the largest metallogenetic provinces of massive polymetallic sulphides in the world. The mining activity in this region goes back thousands of years and has been very intense in the last two centuries, having produced considerable amount of residues which deteriorate the environment of the mining areas and surroundings, mainly due to AMD. This is an extremely acid leachate with high contents of sulphate and metals produced when the piles of mine tailings, particularly those from metallic sulphides extraction, are exposed to air and water (Lowson 1982). The impact of AMD on the environment in the IPB region is still huge nowadays, especially in large mines left abandoned after the exploration period, such as the case of a mine in a small village named Mina de São Domingos, located in Southeast Portugal on the left margin of Guadiana River, near the Spanish frontier (Figure 1). In this mine site, as in others of the IPB, the AMD is not only confined to the pit lake, but also affects several water bodies nearby the mining area, highlighting the need of intervention aiming the remediation of AMD in those sites (Pereira et al. 2004).

While it is known that many organic substrates may sustain directly or at some stage of their degradation sulphate reducing activity, as said above, in practice prior to testing them is not known whether any industrial by-product or waste has toxic compounds for SRB. On the other hand, an organic substrate of a type already tested but from a different local or industry and/or the use of different sulphate reducing bacteria communities does not guarantee similar 
results to the previously reported in literature. Thus, in the present work several low-cost industrial by-products and wastes generated in the Iberian Peninsula (Table 1) were tested for the first time to our knowledge as sources of carbon and electron donors for the anaerobic respiration (sources of energy) of SRB. The tested products were selected based on their availability, on the fact that other products with similar composition were previously successfully tested for the same purpose, and/or on reported evidences of the presence of SRB in those substrates (see table 1).

The research was carried out at the laboratory of Environmental Technologies of the Ecology and Restoration of Riverine, Estuarine and Coastal Habitats (ECOREACH) research group of Centre of Marine Sciences, located at the University of Algarve, in Portugal during 2015 and 2016. The achievements of the present study can be used for the development and implementation of economically viable treatment plants for the bioremediation of AMD in the IPB region, as well as in other regions where these products may also be available. In addition, the achievements obtained can encourage further studies aiming the co-treatment of AMD and some of the tested wastes.

\section{Material and Methods}

\section{$\underline{\text { Substrates tested }}$}

The list of tested substrates and summarized information about their compositions, obtained from published literature and/or from the respective suppliers, is presented in table 1.

The ratio of $\mathrm{COD}$ to $\left[\mathrm{SO}_{4}{ }^{2-}\right]$ in the feed is a key parameter in determining whether SRB would compete with methanogens (e.g. Annachhatre and Suktrakoolvait 2001; Lu et al. 2017; Kiyuna et al. 2017; Jiang et al. 2018). Thus, the $\mathrm{COD} /\left[\mathrm{SO}_{4}{ }^{2-}\right]$ ratio is commonly used to calculate the quantity of organic substrates supplied to feed bioreactors with SRB (Vela et al. 2002; Neculita and Zagury 2008; Kiran et al. 2017). According to the stoichiometry of the process and assuming that all the COD is from compounds that can be utilised by SRB, waters with a $\mathrm{COD} /\left[\mathrm{SO}_{4}{ }^{2-}\right] \mathrm{ratio}$ of 0.67 contain enough sulphate to completely remove the organic matter via sulphate reduction (Vela et al. 2002). However, usually not all carbon compounds present in the organic substrates are suitable for SRB. Moreover, several other factors can influence the competition between SRB and other microorganisms. Therefore, when testing/selecting new substrates to feed SRB based processes it is important to establish their respective optimal COD/[SO $\left.4^{2-}\right]$ ratios (Prasad et al. 1999). Taking this into account, the COD values and $\left[\mathrm{SO}_{4}{ }^{2-}\right]$ were measured in all substrates tested as carbon sources/electron donors. In addition, the tested substrates were analyzed for the concentrations of phosphorous and nitrogen, two important nutrients also essential for SRB growth, and for $\mathrm{pH}$, a chemical parameter critical for biologic activity. For the liquid substrates, dilutions in distilled water were made when necessary to fit the quantification ranges of the analytic methods for COD, $\left[\mathrm{SO}_{4}{ }^{2-}\right],[\mathrm{N}]$ and $[\mathrm{P}]$. For the solids, measurements were made in samples of the aqueous phase obtained after homogenization of $10 \%(\mathrm{w} / \mathrm{v})$ substrate in distilled water and 24 hours leaching without stirring.

\section{$\underline{\text { Experimental design }}$}

The activity of SRB using the different organic substrates as carbon sources/electron donors was tested in duplicates of anaerobic batch reactors inoculated with a SRB enriched culture as follows: (1) positive controls were made in original Postgate B, a medium for SRB in which lactate is the carbon source and electron donor; (2) the tests were made using different quantities of each substrate added to a modified Postgate B medium prepared without lactate and (3) 
the negative controls were prepared in this modified medium without any carbon source/electron donor added. Moreover, some tests and controls were carried out with calcite tailings as a buffering agent and others without it: after a first experiment with a few substrates, in which high sugared contents caused $\mathrm{pH}$ drops to values not suitable for SRB, all further tests and controls were carried out with supplements of calcite tailings to prevent acidification. To monitor the batch reactors, $5 \mathrm{~mL}$ initial culture media and $5 \mathrm{~mL}$ of samples periodically collected with a syringe were analysed, after centrifugation at $4000 \mathrm{rpm}$ during 5 minutes at room temperature. Redox potential (Eh) and soluble $\left[\mathrm{SO}_{4}{ }^{2-}\right]$ and $\left[\mathrm{S}^{2-}\right]$ were monitored as indicators of SRB activity. The $\mathrm{pH}$ was monitored due to its importance as a limiting factor for SRB growth (O'Flaherty et al. 1998; Willow and Cohen 2003). Cultures were monitored weekly until [SO ${ }_{4}^{2-}$ stabilized, which varied from approximately two weeks and nine weeks. Three of the tests with solid substrates (Orange peels, Pine nut shells and Pine cone fragments) were additionally monitored after 4 months. A schematic representation of the experiments performed is provided in figure 2 .

\section{$\underline{\text { Source and enrichment of SRB community }}$}

The SRB community used in these experiments was obtained from sludge collected in the first lagoon of the waste water treatment plant (WWTP) passive lagoon system Faro-Olhão, Portugal. The bacteria were harvested by centrifugation at $2500 \mathrm{~g}$ for $10 \mathrm{~min}$ at room temperature $\left(25^{\circ} \pm 3^{\circ} \mathrm{C}\right)$, washed with Postgate B medium, harvested again by centrifugation in the same conditions and grown in Postgate B medium in anaerobic batch flasks at room temperature before use in this work.

\section{$\underline{\text { Batch tests }}$}

Experiments were performed in anaerobic batch reactors inoculated with 5\% (v/v) of the SRB enriched culture and incubated at room temperature $\left(25^{\circ} \pm 3^{\circ} \mathrm{C}\right)$. In order to achieve the anaerobic conditions: (i) the medium was purged with nitrogen gas before bacterial inoculation, (ii) $5 \%(\mathrm{v} / \mathrm{v})$ of liquid paraffin was added to the medium after inoculation to eliminate oxygen diffusion and (iii) finally the bottles were sealed with butyl rubber stoppers and aluminium crimp seals. Resazurin was added as an indicator to confirm the absence of oxygen. Tests with liquid organic substrates were performed using $120 \mathrm{ml}$ glass bottles containing $100 \mathrm{ml}$ of medium and tests with solid substrates were done in 250 glass bottles containing $200 \mathrm{ml}$ of medium. Media and laboratory glass material used in the batch experiments were sterilized by autoclaving. Moreover, as described in the experimental design section, some batch reactors were supplemented with $10 \%(\mathrm{w} / \mathrm{v})$ of a neutralizing/buffering material: a powder residue from a marble stone cutting and polishing industry mainly composed of magnesium calcite $(* 89 \%)$, quartz $(* 11 \%)$ and traces of illite mineral, as shown by X-ray diffraction analysis (Martins et al. 2009).

\section{$\underline{\text { Substrates dosing }}$}

Several studies have shown that when the $\mathrm{COD} /\left[\mathrm{SO}_{4}{ }^{2-}\right]$ ratio is below 1.7 the SRB prevail over the methanogens (e.g. Wolicka and Borkowski 2009). Thus, it is generally accepted that in mixed populations when this ratio is lower than the mentioned value the SRB have good conditions to succeed. In this work, since the tests were carried out with the substrates diluted in modified (without lactate) Postgate B medium, whenever possible at least one of the tested dilutions 
of each substrate was prepared to obtain a $\mathrm{COD} /\left[\mathrm{SO}_{4}{ }^{2-}\right]$ ratio similar to that one calculated for the original Postgate $\mathrm{B}$ medium (Postgate, 1984) based on its [lactate $\left.\left(\mathrm{C}_{3} \mathrm{H}_{5} \mathrm{O}_{3}\right)\right]$ and $\left[\mathrm{SO}_{4}{ }^{2-}\right]$, which are 2.8 and $1.7 \mathrm{~g} / \mathrm{L}$, respectively.

As demonstrated by van Haandel and van der Lubbe (2007), equation 1 can be used to calculate the theoretical chemical oxygen demand $\left(\mathrm{COD}_{t}\right)$ of a compound with a structural formula $\mathrm{C}_{\mathrm{x}} \mathrm{H}_{\mathrm{y}} \mathrm{O}_{\mathrm{z}}$.

(1) $\mathrm{COD}_{\mathrm{t}}=8 .(4 \mathrm{x}+\mathrm{y}-2 \mathrm{z}) /(12 \mathrm{x}+\mathrm{y}+16 \mathrm{z})$ grams of oxygen per gram of $\mathrm{C}_{\mathrm{x}} \mathrm{H}_{\mathrm{y}} \mathrm{O}_{\mathrm{z}}$

Calculated with this equation, the $\mathrm{COD}_{\mathrm{t}}$ for lactate is $0.99 \mathrm{~g} \mathrm{O} / \mathrm{g} \mathrm{C}_{3} \mathrm{H}_{5} \mathrm{O}_{3}$. Therefore, the $\mathrm{COD}_{\mathrm{t}}$ for the original Postgate B medium, estimated based on its lactate concentration, is $0.99 * 2.8=2.77 \mathrm{~g} \mathrm{O} / \mathrm{L}$. With this value the $\mathrm{COD} /\left[\mathrm{SO}_{4}{ }^{2-}\right]$ ratio of Postgate $\mathrm{B}$ medium is calculated as $2.77 / 1.7=1.63$ (rounded to 1.5 for simplicity).

\section{Liquid substrates}

For the liquid organic substrates, the percentage $(\mathrm{v} / \mathrm{v})$ of each substrate used to make the dilution in modified Postgate $\mathrm{B}$ (without lactate) in order to obtain a $\mathrm{COD} /\left[\mathrm{SO}_{4}{ }^{2-}\right]$ ratio of 1.5 was calculated using both the $\mathrm{COD}$ and [SO $\left.{ }_{4}{ }^{2-}\right]$ values measured for each substrate at the time of the experiment and the $\left[\mathrm{SO}_{4}{ }^{2-}\right]$ of Postgate $\mathrm{B}$ medium $(1700 \mathrm{mg} / \mathrm{L})$. Trying to avoid major dilutions in the $\left[\mathrm{SO}_{4}{ }^{2-}\right]$ that would be adverse for the activity and proliferation SRB, the maximum percentage of liquid substrate tested was in general $20 \%(\mathrm{w} / \mathrm{v})$, even for the cases in which the respective estimated $\mathrm{COD} /\left[\mathrm{SO}_{4}{ }^{2-}\right]$ ratios were below 1.5 (except in the case of municipal wastewater for which a $50 \%$ (v/v) dose was tested).

\section{Solid substrates}

The quantity of solid substrates tested was decided based on $\mathrm{COD} /\left[\mathrm{SO}_{4}{ }^{2-}\right]$ ratios calculated with the $\left[\mathrm{SO}_{4}{ }^{2-}\right]$ in Postgate B medium $(1700 \mathrm{mg} / \mathrm{L})$ and the $\mathrm{COD}$ and $\left[\mathrm{SO}_{4}{ }^{2-}\right]$ values measured in the initial characterization of the substrates (using $10 \%\left(\mathrm{w} / \mathrm{v}\right.$ ) of solid substrate as described above). For example, if the $\mathrm{COD} /\left[\mathrm{SO}_{4}{ }^{2-}\right]$ ratio calculated by this way for a certain solid substrate was 3 , it was assumed that the percentage of that substrate needed to make a $\mathrm{COD} /\left[\mathrm{SO}_{4}{ }^{2-}\right]$ of 1.5 would be $5 \%(\mathrm{w} / \mathrm{v})$. The maximum percentage of solid tested was $10 \%(\mathrm{w} / \mathrm{v})$, even for the cases in which the respective estimated $\mathrm{COD} /\left[\mathrm{SO}_{4}{ }^{2-}\right]$ ratios were below 1.5 .

\section{Analytical Methods}

Redox potential (Eh) and $\mathrm{pH}$ were determined using a pH/E Meter (GLP 21, Crison). The $\left[\mathrm{SO}_{4}{ }^{2-}\right]$ and $\left[\mathrm{S}^{2-}\right]$ were quantified by molecular UV/visible spectrophotometry using the SulfaVer4 (8051, Hach-Lange) and methylene blue (8131, Hach-Lange) methods, respectively, using a DR2800, Hach-Lange spectrophotometer. This equipment was also used to determine COD with cuvette tests for the dichromate method (LCK 514, Hach-Lange) with 2h digestion at $148^{\circ} \mathrm{C}$. To quantify total nitrogen $(\mathrm{N})$ and total phosphorous $(\mathrm{P})$ concentrations, the persulphate acid digestion method (10072, Hach-Lange) and the molybdovanadate with persulphate acid digestion method (10127, Hach-Lange) were used, respectively. The analytical procedures for the Hach-Lange methods were those indicted by the manufacturer. As the number of independently repeated experiments is small $(\mathrm{n}=2)$, rather than showing the results with error values and statistics, the means are presented with the distance to individual data points. 


\section{Results and discussion}

\section{Initial characterization of substrates}

The initial characterization of the tested substrates is shown in table 2. The $\mathrm{pH}$ varied from acid (4.03) to alkali (9.58), highlighting the need of neutralizing the medium $\mathrm{pH}$ after mixing with the substrates.

In what concerns the COD, the high range variation in the tested substrates (from 190 to $\sim 1.2 \cdot 10^{6} \mathrm{mg} / \mathrm{O}_{2} / \mathrm{L}$ ) suggests major differences on their composition in organic compounds. This idea is reinforced by a COD increase in the substrates accompanied with an increase in their [N] and [P] (from $<10$ to $51136 \mathrm{mg} / \mathrm{L}$ and from $<2$ to $17379 \mathrm{mg} / \mathrm{L}$, respectively), two major elements in the composition of cells and thus in biological materials. When comparing the COD and the $[\mathrm{N}]$ and $[\mathrm{P}]$ measured on the tested substrates (Table 2) with the information for these parameters obtained from the literature or from the suppliers (Table 1), in general a concordance in the magnitude of values is seen. The case that deserves comment is the COD in beetroot molasses since the measured value is much higher $\left(\mathrm{more} 576730 \mathrm{mg} / \mathrm{O}_{2} / \mathrm{L}\right.$ ) than the value obtained from the information sent by the supplier. However, it has to be noted that the value presented in table 1 is a theoretical estimation $\left(\mathrm{COD}_{\mathrm{t}}\right)$ based on the composition of beetroot molasses described by the supplier and it is possible that this substrate has more organic compounds than those reported, which could justify the discrepancy between the estimated $\mathrm{COD}_{\mathrm{t}}$ and the measured $\mathrm{COD}$.

Regarding the $\left[\mathrm{SO}_{4}{ }^{2-}\right]$, the variation among the tested substrates is not so wide: eleven substrates have [ $\left.\mathrm{SO}_{4}{ }^{2-}\right]$ below $500 \mathrm{mg} / \mathrm{L}$, six substrates between 500 and $1000 \mathrm{mg} / \mathrm{L}$ and just one is above $1000 \mathrm{mg} / \mathrm{L}$ (2290 mg/L). Therefore, the possibility of having $\mathrm{COD} /\left[\mathrm{SO}_{4}{ }^{2-}\right]$ ratios of 1.5 when diluting the substrates in Postgate $\mathrm{B}$ medium without lactate was mainly depending on the COD values of substrates.

\section{$\underline{\text { Souring problem and } \mathrm{pH} \text { control }}$}

In a first round of tests with beetroot molasses as the carbon source/electrons donor, in which the initial $\mathrm{pH}$ was neutralized with sodium hydroxide but none buffering agent was added to the cultures, in all dilutions tested the $\mathrm{pH}$ decreased to values $(\mathrm{pH}<5.5)$ that inhibited SRB activity. This is shown by the low percentages of sulphate removal $(<$ $10 \%)$ and low production of sulphide $(<10 \mathrm{mg} / \mathrm{L})$ achieved in those cases (tests $\mathrm{N}$. ${ }^{\text {rs }} 7$ to 10 in table 3 and in graphs in supplementary material). That also occurred with the sugared water from the factory of candies, though only in the dilution with $20 \%$ of this substrate. In this case, the removal of sulphate was just $20 \%$ and the [S $\left.\mathrm{S}^{2-}\right]$ reached was only 39 $\mathrm{mg} / \mathrm{L}$ (test N. ${ }^{\text {er }} 3$ in table 3 and in graphs in supplementary material). This phenomenon was expected for the sugar rich substrates. For example, Cao et al. (2012) reported as a major drawback of using sucrose the high content of volatile fatty acids (formic acid, lactic acid and butanedioic acid) resulting from fermentation, which create a souring problem that impacts negatively on the growth of SRB and results in lower sulphate removal rates. Indeed, although SRB bioreactors operating under acidic conditions have already been reported (e.g. at pH 4.5, 4.0, 3.5 and 3.25 in Elliott et al. 1998), the optimum $\mathrm{pH}$ for the growth of most SRB has long been known to be between pH 5 and 9 (Postgate 1984). In this particular case, results previously reported indicate that SRB communities obtained from WWTP sludge collected at Faro, Portugal, as those used in this work, are active in neutral $\mathrm{pH}$ but loose activity in media with $\mathrm{pH}$ values lower than 5.5 (Martins et al. 2009). Nevertheless, the souring problem was solved maintaining the pH between 6 and 8 by adding $10 \%(\mathrm{w} / \mathrm{v})$ of calcite tailings to cultures in additional tests with beetroot molasses from the sugar factory and with 
sugared water from the candies factory, as well as in all further tests with the other organic substrates (except for Carbocal ${ }^{\circledR}$ because it is a lime rich product capable of neutralizing $\mathrm{pH}$ by itself).

\section{$\underline{\text { Sulphate reduction efficiency }}$}

\section{General analysis}

The results obtained with the control cultures prove the success of the followed strategy to test the substrates as carbon sources/electron donors for SRB by using Postgate B medium lacking lactate. In the positive controls with the original Postgate B medium (with lactate) the high removals of sulphate (87 and 92\%) together with the high [S $\left.\mathrm{S}^{2-}\right]$ reached (259 and $304 \mathrm{mg} / \mathrm{L})$ just in 14 days, suggest high activity and proliferation of SRB, while in the negative control with the modified Postgate B (without lactate), the low sulphate removal (25\%) and the low [ $\left.\mathrm{S}^{2-}\right]$ achieved (9 mg/L) indicate low activity and weak or no proliferation of SRB (tests N. ${ }^{\text {ers }} 47$ to 49 in table 3 and in graphs in supplementary material). With this in mind and considering the cultures in which the $\mathrm{pH}$ remained neutral throughout the incubation time, it is possible to say that the sulphate reduction efficiencies, shown by the evolution of $\left[\mathrm{SO}_{4}^{2-}\right]$ and $\left[\mathrm{S}^{2-}\right]$, varied depending on the doses and composition of the tested substrates. The cultures reached levels of sulphate reduction that were classified as high $(\geq 70 \%$ sulphate removal and $\geq 100 \mathrm{mg} / \mathrm{L}$ sulphide produced); moderate $(\geq 30$ and $<70 \%$ sulphate removal and $\geq 30 \mathrm{mg} / \mathrm{L}$ sulphide produced) and low $(<30 \%$ sulphate removal and $<30 \mathrm{mg} / \mathrm{L}$ sulphide produced).

For the liquid substrates it was possible to calculate doses to obtain $\mathrm{COD} /\left[\mathrm{SO}_{4}{ }^{2-}\right]$ ratios of 1.5 for almost all the cases (Table 2). Doses close to those estimates were tested for substrates with relatively high COD values: beetroot molasses, orange molasses with conservative and without conservative, liquor extracted from orange peels, olive mill wastewater (OMW) decanted and not decanted and sugared water from the factory of candies, by descending order of COD values. For the liquid substrates with relatively low COD values (waters from washing the beetroots, waters from washing the orange juice processing equipments, all the wastewaters from the paper pulp and paper factories and the municipal wastewater from the WWTP of Mina de São Domingos) the relatively high doses calculated were not tested since they would have caused major dilutions in the $\left[\mathrm{SO}_{4}{ }^{2-}\right]$, deteriorating the optimal conditions for SRB. For the solid substrates the maximum dose tested was $10 \%(\mathrm{w} / \mathrm{v})$. However, just for orange peel fragments the estimated quantity of product needed for a $24 \mathrm{~h}$ leachate yielding a $\mathrm{COD} /\left[\mathrm{SO}_{4}{ }^{2-}\right]$ ratio of 1.5 was lower than $10 \%(\mathrm{w} / \mathrm{v})$.

In general, high or moderate sulphate reduction efficiencies (as defined above) were achieved in the cultures with doses of substrates estimated to yield $\mathrm{COD} /\left[\mathrm{SO}_{4}{ }^{2-}\right]$ ratios of 1.5 based on their initial characterizations, demonstrating that this is a good strategy to follow when testing new carbon sources/electron donors for SRB. Nevertheless, when the COD and the $\left[\mathrm{SO}_{4}{ }^{2-}\right]$ measured in the beginning of experiments were used to calculate this ratio, its value was in most cases lower (between 0.37 and 0.95) than the targeted 1.5 (Table 3). The reason for this is that the COD values were in most cases lower than the expected according to the initial characterization of substrates, probably because they were stored at room temperature and some degradation of their organic compounds occurred between the initial characterization and the tests. It is worth to note that the possibility of storing the organic substrates to be used as carbon sources/electron donors at room temperature, avoiding the high energy costs associated with refrigeration, would be a huge advantage in favour of implementing SRB based bioremediation processes. 
The bacterial populations in the inoculum were adapted to the carbon source/electron donor lactate that was available in Postgate B, the growth media used for the SRB enrichment, which was also used in the positive controls. Previous phylogenetic analysis of $d s r$ gene sequences from a consortium also enriched from WWTP sludge collected at Faro, Portugal, using Postgate B, revealed three species of genus Desulfovibrio (D. desulfuricans, D. aminophilus and D. fructosovorans) (Martins et al. 2009), which have better growths in media with lactate than with other carbon sources/electron donors. D. desulfuricans was described for the first time as Spirillum desulfuricans more than 100 years ago by Martinus Beijerinck and was later reclassified (Muyzer and Stams 2008). Nutritional studies on this species have shown that growth on other organic substances was poorer than on lactate (MacPherson and Miller 1963). D. aminophilus was discovered on a dairy wastewater treatment plant and has also optimum growth on a medium containing lactate and sulphate, despite being able to use several electron donors with sulphate as an electron acceptor, (Baena et al. 1998). D. fructosovorans was isolated for first time from estuarine sediments and differed from all other described Desulfovibrio species by the ability to degrade fructose (Ollivier et al. 1988). Thus, the longer times to achieve the maximum sulphate removals in the cultures with the substrates tested as carbon sources/electron donors, when compared to the positive controls, indicate that none of those substrates is rich in lactate. In fact, although carbon sources/electron donors that are directly used by SRB have been reported in the composition of some of the tested substrates, their quantities are small when compared to other organic compounds present in those substrates. For example, several shortchain fatty acids (lactic, formic, acetic, and propionic acids) known to be suitable as electron donors for SRB (Cao et al. 2012) are approximately $7 \%$ of the composition of beetroot molasses, while sugars, which are first fermented into simpler products (Maree et al. 1987; Cao et al. 2012), are approximately 47\% of its composition (Table 1). Hence, the inoculated SRB community had to adapt to different carbon sources/electron donors and/or to new bacterial equilibria and mutualistic relationships resulting from the proliferation of species capable of transforming compounds present in the tested substrates into other products suitable for the SRB present in the consortium. For most of the tested substrates, the graphs showing the evolution of the monitored parameters reveal stair profiles with periods of high and low (or no) sulphate reduction activity along the incubation time, which clearly suggests shift points in the respective microbial populations (supplementary material). The test with $5 \%(\mathrm{v} / \mathrm{v})$ of orange molasses without conservative is an elucidative example (Figure 3). The exceptions are sugared water from the factory of cadies and beetroot molasses, which supported more continuous SRB activities and therefore faster removals of sulphate. In all cultures with these substrates high removals of sulphate were reached in two weeks. In the other cases in which high removals of sulphate were also achieved, that was observed just after three weeks (Table 3 and supplementary material).

\section{Liquid by-products}

Exceptionally, for sugared water from the factory of cadies and for beetroot molasses, the COD values measured in the beginning of the experiments were higher than expected. Substrates dilutions in modified Postgate B (v/v) with $20 \%$ of the former and $0.25 \%$ of the second were estimated to yield a COD of $3000 \mathrm{mgO}_{2} / \mathrm{L}$, although the measured $\mathrm{COD}$ values were 3488 and $4035 \mathrm{mgO}_{2} / \mathrm{L}$, respectively. This together with the $\left[\mathrm{SO}_{4}{ }^{2-}\right]$ somewhat lower than the expected for Postgate B medium, resulted in $\mathrm{COD} /\left[\mathrm{SO}_{4}{ }^{2-}\right]$ ratios close to 3 instead of 1.5 , which did not prevent high $\mathrm{SRB}$ activity (values of $79 \%$ and $71 \%$ sulphate reduction were obtained, respectively). In fact, for beetroot molasses a $0.5 \%$ dilution (v/v) with a $\mathrm{COD} /\left[\mathrm{SO}_{4}{ }^{2-}\right]$ ratio of 4.88 revealed an even higher sulphate reduction efficiency (85\%). Initial higher COD

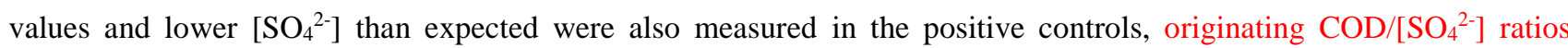


around 2.5, but not affecting the SRB activity which remained very high in those cases. These results obtained with sugared water from the factory of candies and with beetroot molasses are consistent with results obtained by other authors with sugar rich substrates. For example, Wang et al. (2008) studied SRB activities using molasses wastewater from a beetroot sugar refinery as the carbon source at varying $\mathrm{COD} /\left[\mathrm{SO}_{4}{ }^{2-}\right]$ ratios. They observed that at a critical ratio of 2.7, neither COD nor sulphate were in excess for a high sulphate reduction (88\%), while at lower ratios of 1.9 and 0.9 the percentage of sulphate removal decreased to $65 \%$ and $39 \%$, respectively. At even higher ratios of 4.5 and 3.6 high removals of sulphate were still observed $(>95 \%)$, though excessive production of ethanol or acetate was detected.

For the other molasses tested in this work (orange molasses) the dilution supporting the highest sulphate reduction activity (70\%) was also $0.5 \%(\mathrm{v} / \mathrm{v})$ as for beetroot molasses. However, in this case, the analysis performed in the beginning of the tests indicated a much lower $\mathrm{COD} /\left[\mathrm{SO}_{4}{ }^{2-}\right]$ ratio $(<1)$. This may be related to the fact that when the tests started this substrate had the classical odour of alcohol, indicating that some fermentation had already occurred. If so, at that time the relative amount of simplest organic molecules to the amount of more complex organic molecules was relatively higher than at the time of the initial characterization of this substrate. This can justify the much lower COD values than expected (around 400 instead of around $1800 \mathrm{mgO}_{2} / \mathrm{L}$ ) and consequently the lower COD/[SO $\left.{ }_{4}{ }^{2-}\right] \mathrm{ratios}$ in the beginning of these tests. Moreover, this is in agreement with the fact that sulphate reduction was not inhibited since it is known that SRB use small simple organic molecules to obtain energy rather than large complex ones. When orange molasses with conservative CetoSTAT® TMR was used, there was also an odour of alcohol and the initial COD values were also much lower than the expected based on the initial characterization of substrates. Nevertheless, in this case, the sulphate reduction achieved was just moderate (49\%), contrasting with the higher value (70\%) obtained with orange molasses without any conservative. It is evident that the conservative must have inhibited some sort of biological activity that has affected the sulphate reduction efficiency.

In the cultures with the liquor extracted from orange peels (a sugar rich extract used to produce the orange molasses), the COD values measured when the tests started were also lower than expected based on the product characterisation. Due to that, in this case, the assumed optimum dosage (corresponding to a $\mathrm{COD} /\left[\mathrm{SO}_{4}{ }^{2-}\right] \mathrm{ratio}$ of 1.5 ) of this substrate was not tested. For dilutions with $1.25 \%$ and $2.5 \%(\mathrm{v} / \mathrm{v})$ of this substrate, having initial $\mathrm{COD} /\left[\mathrm{SO}_{4}{ }^{2-}\right] \mathrm{ratios}$

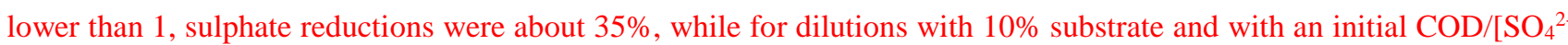
] ratio of 3.18, the removal of sulphate was only $11 \%$. This suggests that in the cultures with less amount of substrate the lack of organic compounds to feed the SRB prevented higher sulphate reduction efficiencies. On the other hand, when more quantity of substrate was tested the SRB activity may have been inhibited by compound(s) with a putative toxic effect on SRB. Eventually an intermediate substrate concentration between $2.5 \%$ and $10 \%$ will result in higher sulphate reduction efficiencies.

It is known for a long time that in mixed bacterial cultures the sugars can be quickly fermented and the resulting products, such as ethanol and short-chain fatty acids, can then be used by SRB (Maree et al. 1987; Cao et al. 2012). Thus, it is most likely that the sulphate reduction activities here discussed for the cultures with the sugar rich by-products were the result of such biological dynamics. Indeed, the souring problem and $\mathrm{pH}$ control discussed above corroborate this idea. 
With Carbocal ${ }^{\circledR}$, the initial $\mathrm{COD}$ and $\left[\mathrm{SO}_{4}{ }^{2-}\right]$ almost did not varied despite the wide different doses tested,

making $\mathrm{COD} /\left[\mathrm{SO}_{4}{ }^{2-}\right]$ ratios ranging only from 0.73 to 0.97 . Nevertheless, for this substrate the SRB activity increased as the tested doses increased and a maximum of 53\% sulphate removal was achieved in 40 days with the highest dose tested of $10 \%(w / v)$. This can be justified by the presence of organic compounds in the solid particles of this substrate which need time to be degraded into simpler molecules suitable as carbon sources/electron donors for SRB. With the three tested substrates composed of relatively large solids (orange peels, pine nut shells and pine nut cones), the high sulphate reductions (> 90\%) achieved after four months of incubation confirm that with enough time the slowly degradable organic solids are probably converted into compounds suitable for the anaerobic respiration of SRB. It has to be said that in such cases dosing the substrate as a function of COD measured in the liquid phase of the medium has probably a limited utility, counting mostly for the initial SRB activity based on the already solubilised compounds available.

The tests with $1 \%$ and $4 \%(\mathrm{w} / \mathrm{v})$ of orange peels, with initial $\mathrm{COD} /\left[\mathrm{SO}_{4}{ }^{2-}\right]$ ratios of 0.85 and 0.94 respectively, revealed high sulphate removals $(>90 \%)$. However, when $8 \%(\mathrm{w} / \mathrm{v})$ of this substrate was used, yielding a $\mathrm{COD}^{2}\left[\mathrm{SO}_{4}{ }^{2-}\right]$ ratio of 1.13 , the removal of sulphate was very low $(6 \%)$, indicating that in this case some compound(s) leached to the medium reach a toxic level for SRB. This idea is supported by the similar behavior observed when liquor extracted from orange peels was used. Orange peels are rich in sugars and have also organic acids (Table 1), one of which, malic acid, already reported as suitable for SRB (Cao et al. 2012). Despite that, with this substrate just a moderate removal of sulphate (47\%) was observed during one month, even if almost total removal (99\%) was detected after four months. This occurred because this substrate is composed of solid tissues with cellulose, hemicelluloses and lignin (Table 1), which are slowly and gradually degraded, allowing the organic compounds to be dissolved and available for the SRB just after relatively long periods. The results obtained in this work together with the results published by Hussain and Qazi (2012), who reported a sulphate reduction of $69 \%$ after fifteen days in Postgate B medium using watermelon rind powder (2\%) instead of lactate, indicate that fruit peels have high potential as carbon source/electron donors for medium/long term remediation processes. Such processes may be useful in passive systems for the decontamination of large water bodies. Indeed, in passive systems the most efficient carbon sources/electron donors are mixtures usually containing relatively easily biodegradable substrates (with soluble sugars, starch, amino acids, and proteins) and recalcitrant ones (with cellulose, hemicelluloses and lignin) (Neculita et al. 2007). Such passive medium/long term bioremediation processes with SRB are useful for example in pit lakes with acidic sulphate rich waters formed by open-pit mining operations (Castro and Moore 2000).

In the case of pine cone fragments and pine nut shells, the high potential for passive medium/long term bioremediation processes is even more evident as they are almost totally composed by the recalcitrant organic compounds cellulose, hemicelluloses and lignin (Table 1). These complex organic polymers cannot be consumed directly by known SRB; however they can be converted into simpler molecules suitable to SRB (Logan et al. 2005). Cellulosic substrates have been tested as sources of organic compounds in SRB bioreactors for more than 20 years (Bechard et al. 1994) and the use of this type of substrates is still a focus of research. For example, Choudhary and Sheoran (2011) observed relatively low sulphate removal efficiencies (25\%) when testing wood chips and sawdust in synthetic AMD water using retention times up to 10 days. More recently, Zhang and Wang (2014) tested the treatment of synthetic AMD water amended with sawdust during 15 days, but again no significant sulphate reduction was observed in this case. Yet these authors also tested this substrate as the sole carbon source for SRB in a modified Postgate C medium during 35 days and in this case a sulphate reduction of 50\% was achieved at the end. This is in accordance with the results obtained in this work when using $10 \%(\mathrm{w} / \mathrm{v})$ pine cone fragments and $10 \%(\mathrm{w} / \mathrm{v})$ pine nut shells in a similarly modified medium: 
moderate removals of sulphate (39 and 36\%) were achieved after a month and high removals (97 and 99\%) were observed after four months (Tests Ners 45 and 46 in table 3 and in graphs in supplementary material). An interesting observation done in this work is that the $\left[\mathrm{S}^{2-}\right]$ measured in the cultures with these cellulosic substrates was always relatively low (between 7 and 20mg/L), even after four months of incubation when total removal of sulphate was achieved. A probable explanation for this can be the adsorption of sulphide to these substrates. Cellulose, as a natural or modified cellulosic material, can be employed as adsorbent for various substances, including organic compounds, metal ions, dyes, etc., and many papers have been published discussing the importance of cellulose-based adsorbents in water pollution control (e.g. Hokkanen et al. 2016). Particularly regarding the adsorption of hydrogen sulphide, it is well known that activated carbon prepared from cellulosic compounds has industrial relevance. Another possible justification for the low $\left[\mathrm{S}^{2-}\right]$ detected despite the high sulphate removal in the tests with the cellulosic substrates, could be the proliferation of sulphidotrophic microorganisms. Perhaps it is worth to explore in future research what happened in this case, as it may lead to the development of biological processes to treat waters contaminated with sulphate without an excessive production of sulphide, which can be very important from an environmental point of view. In fact, in several wastewater treatment plants it is necessary to install systems to capture hydrogen sulphide avoiding the release of this toxic gas to the atmosphere.

\section{Wastewaters}

In the case of water used to wash the equipments from the orange juice factory, considering that its organic compounds are remains of orange juice and extract from orange peels, both rich in sugars, it was expected to support some SRB activity. However, since it is a highly diluted substrate it was predictable that sulphate reduction efficiency would not be very high. The very low initial $\mathrm{COD} /\left[\mathrm{SO}_{4}{ }^{2-}\right]$ ratio of 0.37 in the beginning of the experiment suggests that the lack of nutrients was the cause for just a moderate sulphate reduction efficiency.

The low percentages of sulphate reduction achieved in the cultures supplemented with $20 \%(\mathrm{v} / \mathrm{v})$ of any of the tested wastewaters from the paper pulp and the paper factories, all with very low initial $\mathrm{COD} /\left[\mathrm{SO}_{4}{ }^{2-}\right] \mathrm{ratios}(<0.25)$, reinforce the idea that low values of this ratio indicate insufficient nutrients for the reduction of all sulphate available.

With water from washing beetroots, the maximum sulphate removal of $31 \%$, achieved for cultures with $20 \%$ of this substrate in approximately one month, also suggests insufficient nutrients available for SRB. However, the hypothesis that more time would have been necessary for the degradation of part of the organic matter present this substrate, namely as slowly degradable solid particles from the materials used to fertilize the beetroot fields and/or beetroot fragments (Table 1), should be considered. This hypothesis is supported by the fact that similar initial COD and $\left[\mathrm{SO}_{4}{ }^{2-}\right]$ values were measured despite the different doses used, resulting in similar $\mathrm{COD} /\left[\mathrm{SO}_{4}{ }^{2-}\right]$ ratios $(0.77$ and 0.79$)$, together with the fact that the higher quantity of substrate used the higher SRB activity was achieved, as it also happened in the tests with Carbocal® (discussed above).

The best sulphate reduction activities achieved in one month when using OMW as carbon source/electrons donor were obtained with percentages approximately 3 times greater than the percentages calculated to make a $\mathrm{COD} /\left[\mathrm{SO}_{4}{ }^{2-}\right]$ ratio of 1.5 . This suggests that just part of the organic compounds present in this substrate is used by SRB during this incubation period. In OMW most part of organic matter corresponds to oils and fats (1.67 to $8.16 \%)$; 
however, it also contains sugars (0.1 to $0.9 \%)$, polyalcohols $(\sim 1 \%)$ and volatile organic acids $(\sim 0.1 \%)$ (Table 1$)$. Focusing on sugars, which can be used by SRB after relatively rapid fermentation, and comparing the tested dilutions of OMW with the tested dilutions of the two substrates richest in sugars (beetroot and orange molasses), it can be seen that: (1) The best dilution for both molasses was $0.5 \%(\mathrm{v} / \mathrm{v})$ and these substrates had approximately $45 \%$ sugars in their composition, which means that there was around $0.22 \%$ of sugars in the best cultures containing these substrates; (2) The best dilution for sulphate reduction with OMW corresponds to a concentration of $20 \%(\mathrm{v} / \mathrm{v})$. Thus, supposing that this substrate had $0.44 \%$ of sugars in its composition (half the maximum value described in table 1 ), the best cultures with it would have $0.088 \%$ of sugars. This percentage is almost half the quantity of sugars present in the best cultures with molasses. Therefore, it can be said that probably sugars have played a major role in supporting the SRB activity in the cultures with OMW. In addition, it is known that alcohols and volatile organic acids can be directly used by SRB. Thus, based on a typical composition of OMW (Table 1) it can be estimated that approximately $0.2 \%$ of polyalcohols and $0.02 \%$ of volatile organic acids probably contributed for the SRB activity in the cultures with $20 \%$ OMW. Moreover, polyphenols are also important in OMW (0.0002 to 1.5\%). It has been discovered that one of its most abundant phenolic compounds (1,4-tyrosol) can be oxidized by a SRB (Desulfovibrio marrakechensis) isolated for the first time from OMW in Morocco (Chamkh et al. 2009) and identified by 16S rRNA gene sequence analysis in OMW from Greece after treatment tests using amendments of laccase and cellobiose dehydrogenase (Prasetyo et al. 2015). This raises the hypothesis that SRB with this metabolic pathway may exist as well in OMW ponds in Portugal. If so, the bacterial communities in cultures with this substrate could have used this compound for sulphate reduction. This speculative analysis about which compounds of this substrate can support the biological activity of SRB communities is just a starting point for further research work aiming to explore this issue. Nevertheless, these results, proving that OMW is a good carbon source/electrons donor for SRB, open the way for the development of what would be a very interesting bioremediation process for this type of wastes, which are generated in high amount during the olive oil extraction process and have become an important challenge since its direct disposal in nature causes extremely negative impacts (Amaral et al. 2008).

In municipal wastewater (sewage), the organic pollutants are mainly proteins, saccharides and aliphatics (at least $78 \%$ of the total COD), most of them macromolecules that constitute slowly biodegradable organic matter, though rapidly biodegradable organic components and readily dissolved compounds such as micromolecular organic acids and alcohols are also present (e.g. Zhang et al. 2016). The reduction of sulphate in the tests with municipal wastewater from Mina de São Domingos started just one week after inoculation and continued during about one month while sulphate was present (graphs for tests $\mathrm{N}^{\mathrm{er}} 43$ and 44 in supplementary material). This suggests that probably the readily and rapidly degradable dissolved compounds had been consumed during the transportation and storage and that the SRB activity might have been sustained by slowly biodegradable organic components after their transformation into simplest products. The municipal wastewater used in this work was collected, immediately transported at $25^{\circ} \pm 3^{\circ} \mathrm{C}$ during three hours and then stored at $4^{\circ} \mathrm{C}$ for three days before its use in the experiments. These results seem to contradict the work published by Kumar et al. (2011), which suggests that the presence of rapidly biodegradable and readily dissolved organic components in sewage is critical for an effective SRB activity. These authors reported that though sewage stored at $4{ }^{\circ} \mathrm{C}$ had retained a high total organic carbon equivalent to prior storage, it failed to increase dissolved organic carbon and failed to stimulate SRB activity. After addition of labile organic carbon consisting of lactic acid and ethanol to the microcosm, effective removal of sulphate was observed, indicating biological activity of SRB. However, it should be noted that the duration of storage used by these authors was 3 years, a much longer period than the three days storage in this work. 
Probably, during those three years the slowly degradable organic compounds with potential to sustain SRB activity were consumed due to some biological activity occurring at $4^{\circ} \mathrm{C}$. All these findings prove that municipal wastewater can be used as carbon source/electrons donor for SRB based processes, provided that it is immediately used and not after storage.

\section{Conclusions}

This work demonstrates the high potential of several industrial by-products and wastes as carbon sources/electron donors for SRB, which being available in the Iberian Peninsula can be easily used in bioremediation processes to treat AMD in the IPB region.

Moreover, it reports the approximate time needed to achieve high sulphate reduction with these substrates and the required doses of substrate (\% v/v or $\% \mathrm{w} / \mathrm{v}$, depending if the substrate is liquid or solid) and respective $\left.\mathrm{COD}_{\text {/ }} \mathrm{SO}_{4}{ }^{2-}\right]$ ratios that favour SRB activity in sulphate rich aqueous environments with neutral $\mathrm{pH}$.

Some substrates support high SRB activity in relatively short periods of two to four weeks: sugared water from the factory of candies $(20 \%(\mathrm{v} / \mathrm{v})$ dose, 3.10 ratio $)$; beetroot molasses ( 0.25 to $0.5 \%(\mathrm{v} / \mathrm{v})$ dose, 3.17 to 4.88 ratio); OMW not decanted (20\% (v/v) dose, 1.08 ratio); OMW decanted (20\% (v/v) dose, 1.63 ratio); orange molasses without conservative $(0.5 \%(\mathrm{v} / \mathrm{v})$ dose, 0.61 ratio $)$ and municipal wastewater from a small village near an inactive mine in the IPB (20 to $50 \%$ (v/v) dose, 0.90 to 2.34 ratio).

Others substrates require longer periods, up to four months, to sustain high sulphate reduction efficiencies: orange peel fragments (1 to $4 \%$ (w/v) dose, 0.85 to 0.94 ratio); pine nut shells (10\% (w/v) dose, 0.92 ratio) and pine cone fragments $(10 \%(\mathrm{w} / \mathrm{v})$ dose, 0.90 ratio $)$.

\section{Supplementary data}

Supplementary data associated with this article can be found in the online version: graphs showing the evolution of measured parameters along the experiments.

\section{Acknowledgements}

Funding: The research leading to these results has received funding from the European Union's Seventh Framework Programme (FP7/2007-2013) managed by REA-Research Executive Agency (http://ec.europa.eu/research/rea) under grant agreement $\mathrm{n}^{\circ} .619101$; and the Portuguese Foundation for Science and Technology (FCT) through the project UID/Multi/04326/2013.

The authors also wish to acknowledge the company Águas do Algarve, namely Eng. Joaquim Freire and Patrício Fontinha, for supplying the WWTP sludge used to enrich cultures with SRB and companies that supplied the substrates tested as sources of carbon sources/electron donors (and the persons involved in this supply): Orange juice plant LARA Laranja do Algarve S.A. (Eng. Pedro Pacheco), Factory of candies Dulciora (anonymous collaboration), Sugar processing plant Azucarera (Eng. Maria Hernandez Garcia), Olive mill Lagar Santa Catarina (Eng. Renato Rocha), 
Águas Públicas do Alentejo, WWTP Mina de São Domingos (Eng. Olga Martins), Paper and paper pulp factories Navigator Company (Eng. Luis Medeiros Machado and Eng. Patrícia Castellano Rodrigues).

\section{References}

Almendros AI, Martín-Lara MA, Ronda A, Pérez A, Blázquez G, Calero M (2015) Physico-chemical characterization of pine cone shell and its use as biosorbent and fuel. Bioresour Technol 196:406-412. doi: 10.1016/j.biortech.2015.07.109

Amaral C, Lucas MS, Coutinho J, Crespí AL, do Rosário Anjos M, Pais C (2008) Microbiological and physicochemical characterization of olive mil wastewaters from a continuous olive mill in Northeastern Portugal. Bioresour Technol 99:7215-7223. doi: 10.1016/j.biortech.2007.12.058

Annachhatre AP, Suktrakoolvait S (2001) Biological sulphate reducing using molasses as a carbon source. Water Environ Res 73:118-126. doi: 10.2175/106143001X138778

Azbar N, Bayram A, Filibeli A, Muezzinoglu A, Sengul F, Ozer A (2004) A review of wastes management options in olive oil production. Crit Rev Env Sci Tec 34: 209-247. doi: 10.1080/10643380490279932

Baena S, Fardeau ML, Labat M, Ollivier B, Garcia JL, Patel BKC (1998) Desulfovibrio aminophilus sp. nov., a Novel Amino Acid Degrading and Sulfate Reducing Bacterium from an Anaerobic Dairy Wastewater Lagoon. Syst Appl Microbiol 21(4):498-504. doi:10.1016/S0723-2020(98)80061-1

Bechard G, Yamazaki H, Gould WD, Bedard P (1994) Use of cellulosic substrates for the microbial treatment of acid mine drainage. J Environ Qual 23:111-116. doi: 10.2134/jeq1994.00472425002300010017x

Buzzini AP, Pires EC (2007) Evaluation of a upflow anaerobic sludge blanket reactor with partial recirculation of effluent used to treat wastewaters from pulp and paper plants. Bioresour Technol 98:1838-1848. doi: 10.1016/j.biortech.2006.06.030

Cao J, Zhang G, Mao Z, Li Y, Fang F, Chao Y (2012) Influence of electron donors on the growth and activity of sulphate-reducing bacteria. Int J Miner Process 106-109:58-64. doi: 10.1016/j.minpro.2012.02.005

Castro JM, Moore JN (2000) Pit lakes: their characteristics and the potential for their remediation. Environ Geol 39:1254-1260. doi: 10.1007/s002549900100

Chamkh F, Spröer C, Lemos PC, Besson S, El Asli AG, Bennisse R, Labat M, Reis M, Qatibi AI (2009) Desulfovibrio marrakechensis sp. nov., a 1,4-tyrosol-oxidizing, sulphate-reducing bacterium isolated from olive mill wastewater. Int J Syst Evol Microbiol 59:936-942. doi: 10.1099/ijs.0.003822-0

Chen W, Horan NJ (1998) The Treatment of a High Strength Pulp and Paper Mill Effluent for Wastewater ReUse. Environ Technol 19:163-171. doi: 10.1080/09593330.1998.9618627

Choudhary RP, Sheoran AS (2011) Comparative study of cellulose waste versus organic waste as substrate in a sulphate reducing bioreactor. Bioresour Technol 102:4319-4324. doi: 10.1016/j.biortech.2010.08.126

Clements RL (1964) Organic acids in citrus fruits. I. Varietal differences. J Food Sci 29:276-280. doi: 10.1111/j.1365-2621.1964.tb01731.x 
Costa JM, Rodriguez RP, Sancinetti GP (2017) Removal sulfate and metals $\mathrm{Fe}^{+2}, \mathrm{Cu}^{+2}$, and $\mathrm{Zn}^{+2}$ from acid mine drainage in an anaerobic sequential batch reactor. J Environ Chem Eng 5(2):1985-1989. doi: 10.1016/j.jece.2017.04.011

Costa MC, Duarte JC (2005) Bioremediation of acid mine drainage using acidic soil and organic wastes for promoting sulphate-reducing bacteria activity on a column reactor. Water Air Soil Poll 165:325-345. doi: $10.1007 / \mathrm{s} 11270-005-6914-7$

Das BK, Gauri SS, Bhattacharya J (2013) Sweetmeat waste fractions as suitable organic carbon source for biological sulfate reduction. Int Biodeterior Biodegradation 82:215-223. doi: 10.1016/j.ibiod.2013.03.027

Dev S, Roy S, Bhattacharya J (2017) Optimization of the operation of packed bed bioreactor to improve the sulfate and metal removal from acid mine drainage. J Environ Manage 200:135-144. doi:10.1016/j.jenvman.2017.04.102

Elliott P, Ragusa S, Catcheside D (1998) Growth of sulphate-reducing bacteria under acidic conditions in an upflow anaerobic bioreactor as a treatment system for acid mine drainage. Water Res 32:3724-3730. doi: 10.1016/S00431354(98)00144-4

Hao T, Xiang P, Mackey HR, Chi K, Lu H, Chui H, van Loosdrecht MCM, Chen GH (2014) A review of biological sulphate conversions in wastewater treatment. Water Res 65:1-21. doi: 10.1016/j.mineng.2016.02.008

Hokkanen S, Bhatnagar A, Sillanpää M (2016) A review on modification methods to cellulose-based adsorbents to improve adsorption capacity. Water Res 91:156-173. doi: 10.1016/j.watres.2016.01.008

Hussain A, Qazi J (2016) Application of sugarcane bagasse for passive anaerobic biotreatment of sulphate rich wastewaters. Appl Water Sci 6(2):205-211. doi:10.1007/s13201-014-0226-2

Hussain A, Qazi JI (2012) Biological sulphate reduction using watermelon rind as a carbon source. Biologia (Pakistan) 58:85-92

Jiang Y, Qin Y, Yu F, Li H, Liu K (2018) Is COD/SO ${ }_{4}{ }^{2-}$ ratio responsible for metabolic phase-separation shift in anaerobic baffled reactor treating sulfate-laden wastewater? Int Biodeterior Biodegradation 126:37-44. doi: 10.1016/j.ibiod.2017.08.013

Kim YM, Kim S, Han TU, Park YK, Watanabe C (2014) Pyrolysis reaction characteristics of Korean pine (Pinus Koraiensis) nut shell. J Anal Appl Pyrol 110:435-441. doi: 10.1016/j.jaap.2014.10.013

Kiran MG, Pakshirajan K, Das G (2017) An overview of sulfidogenic biological reactors for the simultaneous treatment of sulfate and heavy metal rich wastewater. Chem Eng Sci 158:606-620. doi:10.1016/j.ces.2016.11.002

Kiyuna LS, Fuess LT, Zaiat M (2017) Unraveling the influence of the COD/sulfate ratio on organic matter removal and methane production from the biodigestion of sugarcane vinasse. Bioresour Technol 232:103-112. doi:10.1016/j.biortech.2017.02.028

Kumar RN, McCullough CD, Lund MA (2011) How does storage affect the quality and quantity of organic carbon in sewage for use in the bioremediation of acidic mine waters? Ecol Eng 37:1205-1213. doi: 10.1016/j.ecoleng.2011.02.021 
Lefticariu L, Walters ER, Pugh CW, Bender KS (2015) Sulfate reducing bioreactor dependence on organic substrates for remediation of coal-generated acid mine drainage: Field experiments. Appl Geochem 63:70-82. doi:org/10.1016/j.apgeochem.2015.08.002

Li YL, Wang J, Yue ZB, Tao W, Yang HB, Zhou YF, Chen TH (2017) Simultaneous chemical oxygen demand removal, methane production and heavy metal precipitation in the biological treatment of landfill leachate using acid mine drainage as sulfate resource. J Biosci Bioeng 124(1):71-75. doi:10.1016/j.jbiosc.2017.02.009

Liamleam W, Annachatre AP (2007) Electron donors for biological sulfate reduction. Biotechnol Adv 25:452463. doi: 10.1016/j.biotechadv.2007.05.002

Logan MV, Reardon KF, Figueroa LA, McLain JET, Ahmann DM (2005) Microbial community activities during establishment, performance, and decline of bench-scale passive treatment systems for mine drainage. Water Res 39:4537-4551. doi: 10.1016/j.watres.2005.08.013

Lowson RT (1982) Aqueous oxidation of pyrite by molecular oxygen. Chem Rev 82:461-497. doi: 10.1021/cr00051a001

Lu X, Zhen G, Ni J, Kubota K, Li YY (2017) Sulfidogenesis process to strengthen re-granulation for biodegradation of methanolic wastewater and microorganisms evolution in an UASB reactor. Water Res 108:137-150. doi:10.1016/j.watres.2016.10.073

MacPherson R, Miller JDA (1963) Nutritional Studies on Desulfovibrio desulfuricuns using Chemically Defined Media. Microbiol 31:365-373. doi:10.1099/00221287-31-3-365

Maree JP, Gerber A, Hill E (1987) An Integrated Process for Biological Treatment of Sulphate-Containing Industrial Effluents. J Water Pollut Con F 59:1069-1074. Stable URL: http://www.jstor.org/stable/25043436

Martins M, Faleiro ML, Barros RJ, Veríssimo AR, Costa MC (2009) Biological sulphate reduction using food industry wastes as carbon sources. Biodegradation 20:559-567. doi: 10.1007/s10532-008-9245-8

Michailides MK, Tekerlekopoulou AG, Akratos CS, Coles S, Pavlou S, Vayenas DV (2015) Molasses as an efficient low-cost carbon source for biological $\mathrm{Cr}(\mathrm{VI})$ removal. J Hazard Mater 8:95-105. doi: 10.1016/j.jhazmat.2014.08.004

Miran W, Jang J, Nawaz M, Shahzad A, Jeong SE, Jeon CO, Lee DS (2017) Mixed sulfate-reducing bacteriaenriched microbial fuel cells for the treatment of wastewater containing copper. Chemosphere 189:134-142. doi: 10.1016/j.chemosphere.2017.09.048

Muhammad SN, Kusin FM, Madzin Z (2017) Coupled physicochemical and bacterial reduction mechanisms for passive remediation of sulfate- and metal-rich acid mine drainage. Int J Environ Sci Technol. doi:10.1007/s13762-0171594-6

Mulopo J (2016) Pilot scale assessment of the continuous biological sulphate removal from coal acid mine effluent using grass cutting as carbon and energy sources. J Water Process Eng 11:104-109. doi:10.1016/j.jwpe.2016.04.001

Muyzer G, Stams AJ (2008) The ecology and biotechnology of sulphate-reducing bacteria. Nat Rev Microbiol 6(6):441-54. doi:10.1038/nrmicro1892 
Neculita CM, Zagury GJ (2008) Biological treatment of highly contaminated acid mine drainage in batch reators: Long-term treatment and reactive mixture characterization. J Hazard Mater 157:359-366. doi: 10.1016/j.jhazmat.2008.01.002

Neculita CM, Zagury GJ, Bussiere B (2007) Passive treatment of acid mine drainage in bioreactors using sulphate-reducing bacteria: critical review and research needs. J Environ Qual 36:1-16. doi: 10.2134/jeq2006.0066

O'Flaherty V, Mahony T, O'Kennedy R, Colleran E (1998) Effect of pH on growth kinetics and sulphide toxicity thresholds of a range of methanogenic, syntrophic and sulphate-reducing bacteria. Process Biochem 33(5):555-569. doi: $10.1016 / \mathrm{S} 0032-9592(98) 00018-1$

Ollivier B, Cord-Ruwisch R, Hatchikian EC, Garcia JL (1988) Characterization of Desulfovibrio fructosovorans sp. nov. Arch Microbiol 149:447-450. doi: 10.1007/BF00425586

Parshina SN, Sipma J, Henstra AM, Stams AJ (2010) Carbon Monoxide as an Electron Donor for the Biological Reduction of Sulphate. Int J Microbiol 2010:319527. doi:10.1155/2010/319527

Pereira R, Ribeiro R, Gonçalves F (2004) Plan for an Integrated Human and Environmental Risk Assessment in the S. Domingos Mine Area (Portugal). Hum Ecol Risk Assess 10:543-578. doi:10.1080/10807030490452197

Postgate JR (1984) The Sulphate-Reducing Bacteria. 2nd edn. Cambridge Univ. Press. Cambridge

Prasad D, Wai M, Bérubé P, Henry JG (1999) Evaluating Substrates in the Biological Treatment of Acid Mine Drainage. Environ Technol 20:449-458. doi: 10.1080/09593332008616840

Prasetyo EN, Rodríguez RD, Lukesch B, Weiss S, Murkovic M, Katsoyannos E, Sygmund C, Ludwig R, Nyanhongo GS, Guebitz GM (2015) Laccase-cellobiose dehydrogenase-catalyzed detoxification of phenolic-rich olive processing residues. Int J Environ Sci Technol 12:1343-1352. doi:10.1007/s13762-014-0526-y

Rambabu N, Panthapulakkal S, Sain M, Dalai AK (2016) Production of nanocellulose fibers from pinecone biomass: Evaluationand optimization of chemical and mechanical treatment conditions on mechanical properties of nanocellulose films. Ind Crop Prod 83:746-754. doi: 10.1016/j.indcrop.2015.11.083

Raunkjaer K, Jacobsen TH, Nielsen PH (1994) Measurement of pools of protein, carbohydrate and lipid in domestic wastewater. Water Res 28:251-262. doi: 10.1016/0043-1354(94)90261-5

Relvas JMRS, Barriga FJAS, Longstaffe FJ (2006) Hydrothermal Alteration and Mineralization in the NevesCorvo Volcanic-Hosted Massive Sulfide Deposit, Portugal. II. Oxygen, Hydrogen, and Carbon Isotopes. Econ Geol 101(4):791-804. doi: 10.2113/gsecongeo.101.4.791

Rivas B, Torrado A, Torre P, Converti A, Dominguez JM (2008) Submerged Citric Acid Fermentation on Orange Peel Autohydrolysate. J Agric Food Chem 56:2380-2387. doi: 10.1021/jf073388r

Shofinita D, Feng S, Langrish TAG (2015) Comparing yields from the extraction of different citrus peels and spray drying of the extracts. Adv Powder Technol 26:1633-1638. doi: 10.1016/j.apt.2015.09.007

van Haandel AC, van der Lubbe JGM (2007) Handbook Biological Waste Water Treatment - Design and optimization of activated sludge systems. Quist Publishing. Leidschendam 
Vasquez Y, Escobar MC, Neculita CM, Arbeli Z, Roldan F (2016) Selection of reactive mixture for biochemical passive treatment of acid mine drainage. Environ Earth Sci 75:576. doi:10.1007/s12665-016-5374-2

Vela FJ, Zaiat M, Foresti E (2002) Influence of the COD to sulphate ratio on the anaerobic organic matter degradation kinetics. Water SA 28:213-216. doi: 10.4314/wsa.v28i2.4887

Wang A, Ren N, Wang X, Lee D (2008) Enhanced sulphate reduction with acidogenic sulphate-reducing bacteria. J Hazard Mater 154:1060-1065. doi: 10.1016/j.jhazmat.2007.11.022

Willow MA, Cohen RRH (2003) pH, dissolved oxygen, and adsorption effects on metal removal in anaerobic bioreactors. J Environ Qual 32:1212-1221. doi:10.2134/jeq2003.1212

Wolicka D, Borkowski A (2009) Phosphogypsum biotransformation in cultures of sulphate reducing bacteria in whey. Inter Biodeter Biodegr 63:322-327. doi: 10.1016/j.ibiod.2008.09.011

Zerrouki S, Rihani R, Bentahar F, Belkacemi K (2015) Anaerobic digestion of wastewater from the fruit juice industry: experiments and modeling. Water Sci Technol. 72:123-34. doi: 10.2166/wst.2015.193

Zhang M, Wang H (2014) Organic wastes as carbon sources to promote sulphate reducing bacterial activity for biological remediation of acid mine drainage. Miner Eng 69:81-90. doi: 10.1016/j.mineng.2014.07.010

Zhang QH, Jin PK, Ngo HH, Shi X, Guo WS, Yang SJ, Wang XC, Wang X, Dzakpasu M, Yang WN, Yang L (2016) Transformation and utilization of slowly biodegradable organic matters in biological sewage treatment of anaerobic anoxic oxic systems. Bioresour Technol 218:53-61. doi: 10.1016/j.biortech.2016.06.068

\section{Figure captions}

Figure 1 - Iberian Pyrite Belt geological map indicating the most important mining sites (adapted from Relvas et al. 2006).

Figure 2 - Schematic representation of the experimental design.

Figure 3 - Evolution of parameters measured in the cultures with $5 \%$ (v/v) of orange molasses without conservative. Values are averages \pm mean absolute deviations (in some points bars are smaller than the line width, thus not visible)

\section{Table captions}

Table 1 - Typical compositions of tested substrates and justifications to be tested

Table 2 - Characterization of the tested substrates in terms of $\mathrm{pH}, \mathrm{COD},\left[\mathrm{SO}_{4}{ }^{2-}\right],[\mathrm{N}]$ and $[\mathrm{P}]$ plus the percentages of substrates estimated to obtain $\mathrm{COD} /\left[\mathrm{SO}_{4}{ }^{2-}\right]$ ratios of 1.5 when diluted in Postgate $\mathrm{B}$ medium without lactate 
1 reducing bacteria) and values achieved during incubation 


\section{Tables}

\section{Table 1}

\begin{tabular}{|c|c|c|c|}
\hline Substrates and their suppliers & Typical composition & $\begin{array}{c}\text { Source of composition } \\
\text { information }\end{array}$ & Why tested? \\
\hline $\begin{array}{l}\text { - Sugared water (from an } \\
\text { homogenization tank) }\end{array}$ & $\begin{array}{l}\text { Water with sucrose. } \\
\mathrm{COD}=5 \text { to } 11 \mathrm{~g} \mathrm{O}_{2} / \mathrm{L}\end{array}$ & Supplier & $\begin{array}{l}\text { Foreseeable success in the light of works } \\
\text { already published with other by-products } \\
\text { from candy factories (e.g. sweetmeat waste } \\
\text { fractions (Das et al. 2013)). }\end{array}$ \\
\hline \multicolumn{4}{|l|}{$\begin{array}{l}\text { Sugar from beetroot processing factory } \\
\text { Azucarera located in Jerez de la Frontera, } \\
\text { Spain: }\end{array}$} \\
\hline - Beetroot molasses & $\begin{array}{l}\text { Sucrose }=45.5 \%(\mathrm{w} / \mathrm{v}) \\
\text { Glucose }=0.14 \%(\mathrm{w} / \mathrm{v}) \\
\text { Fructose }=0.45 \%(\mathrm{w} / \mathrm{v}) \\
\text { Rafinose }=1.3 \%(\mathrm{w} / \mathrm{v}) \\
\text { Lactic acid }=3.2 \%(\mathrm{w} / \mathrm{v}) \\
\text { Formic acid }=0.53 \%(\mathrm{w} / \mathrm{v}) \\
\text { Acetic acid }=0.69 \%(\mathrm{w} / \mathrm{v}) \\
\text { Propionic acid }=2.5 \%(\mathrm{w} / \mathrm{v}) \\
\text { COD }_{\text {(theoretical for these compounds) }}=615.27 \mathrm{~g} \mathrm{O} / \mathrm{L}\end{array}$ & Supplier & $\begin{array}{l}\text { Foreseeable success, in the light of the } \\
\text { works already published with other type of } \\
\text { molasses (e.g. sugarcane molasses } \\
\text { (Michailides et al. 2015)). }\end{array}$ \\
\hline - Water from washing the beetroots & $\begin{array}{l}\text { Water contaminated with soil and agricultural } \\
\text { fertilizers. } \\
\mathrm{COD}=2.5 \mathrm{~g} \mathrm{O}_{2} / \mathrm{L} \text {. }\end{array}$ & Supplier & $\begin{array}{l}\text { After detection of sulphidric gas in this } \\
\text { substrate, the presence of SRB was } \\
\text { confirmed by counts with the method of the } \\
\text { most probable number using Postgate } \mathrm{E} \text { as } \\
\text { growth medium (unpublished data). }\end{array}$ \\
\hline \multicolumn{2}{|l|}{$\begin{array}{l}\text { Olive oil Press Lagar de Santa Catarina, } \\
\text { located in Santa Catarina da Fonte do Bispo, } \\
\text { Portugal: }\end{array}$} & & $\begin{array}{l}\text { Portugal and Spain are among the five } \\
\text { largest producers of olive oil in the world } \\
\text { and the extraction process generates high }\end{array}$ \\
\hline
\end{tabular}


$\mathrm{COD}=7.45$ to $220 \mathrm{~g} \mathrm{O} 2 / \mathrm{L}$

Organic matter $=16.7$ to $81.6 \mathrm{~g} / \mathrm{L}$ (1.67 to

$8.16 \%(\mathrm{w} / \mathrm{v}))$

Oils and fats $=2.47$ to $62.3 \mathrm{~g} / \mathrm{L}(0.247$ to

$6.23 \%(\mathrm{w} / \mathrm{v})(\mathrm{w} / \mathrm{v}))$

Sugars $=1.3$ to $8.8 \mathrm{~g} / \mathrm{L}(0.13$ to $0.88 \%(\mathrm{w} / \mathrm{v}))$

Polyphenols $=0.002$ to $11.5 \mathrm{~g} / \mathrm{L}(0.0002$ to 1.5

$\%(\mathrm{w} / \mathrm{v}))$

- Olive mill wastewater decanted

Volatile organic acids $=0.78$ to $1 \mathrm{~g} / \mathrm{L}(0.078$ to

$0.1 \%(\mathrm{w} / \mathrm{v}))$

Polyalcohols $=10$ to $11 \mathrm{~g} / \mathrm{L}(1$ to $1.1 \%(\mathrm{w} / \mathrm{v}))$

Phosphorus $=0.012$ to $0.163 \mathrm{~g} / \mathrm{L}$
Nitrogen $=0.023$ to $1.2 \mathrm{~g} / \mathrm{L}$

Orange juice factory LARA - Laranja do

Algarve, S.A., located in Silves, Portugal:

- Orange molasses with conservative

(CetoSTAT® TMR)

Sugars $($ Brix $)=43$ to $50 \%$

Proteins $<3 \%$

- Orange molasses without conservative Fats $<1 \%$

- Liquor extracted from orange peels

A sugar rich extract obtained by press, after

mixing the peels with slaked lime. It is used to

produce the orange molasses by evaporation.

Soluble sugars $=16.9 \%$ dry weight

Starch $=3.75 \%$ dry weight

Cellulose $=9.21 \%$ dry weight

Hemicelluloses $=10.5 \%$ dry weight

Lignin $=0.84 \%$ dry weight

Pectins $=42.5 \%$ dry weight

Fats $=1.95 \%$ dry weight

Proteins $=6.50 \%$ dry weight

Citric acid $=0.01 \mathrm{meq} / \mathrm{g}$ dry weight

Malic acid $=0.02 \mathrm{meq} / \mathrm{g}$ dry weight

Oxalic acid $=0.105 \mathrm{meq} / \mathrm{g}$ dry weight

Malonic acid $=0.025 \mathrm{meq} / \mathrm{g}$ dry weight

Total Phenols $=5 \mathrm{mg}$ gallic acid equivalents $/ \mathrm{g}$

fresh weight
(Azbar et al. 2004;

Amaral et al. 2008) amount of olive mill wastewaters.

A novel SRB was isolated from these wastewaters (Chamkh et al. 2009) and they have been associated with smells characteristic of hydrogen sulfide. Both facts suggest that these wastewaters have in their composition suitable sources of carbon/electron donors for SRB.
- Orange peel fragments

- Water from washing the equipments
Water contaminated with orange juice and orange peel extract.
Supplier

Supplier

(Rivas et al. 2008)

Foreseeable success, in the light of the works already published with other sugar rich products (e.g. sweetmeat wastes and sugarcane molasses Das et al. 2013; Michailides et al. 2015).
Supplier

High measurements of hydrogen sulfide in biogas obtained by digestion of wastewaters from the fruit juice industry (e.g. Zerrouki et al. 2015) suggest they have suitable carbon sources/electron donors for SRB. 
Paper pulp and paper factories Navigator Company, located in Setubal, Portugal:

- Pulp factory alkaline wastewater

- Pulp factory neutral wastewater

- Paper factory wastewater

- Paper factory wastewater

- Final mixed treated effluent

\section{Phosphorus $=0.003 \mathrm{~g} / \mathrm{L}$ \\ Nitrogen $=0.002 \mathrm{~g} / \mathrm{L}$}

Sodium sulphate $=2.3 \mathrm{~g} / \mathrm{L}$

variety of organic and inorganic contaminants

that mostly originate from tannins, lignins,

(Buzzini and Pires

2007)

$\mathrm{COD}=1.3 \mathrm{~g} \mathrm{O}_{2} / \mathrm{L}$

Phosphorus $=0.003 \mathrm{~g} / \mathrm{L}$

itrogen $=0.003 \mathrm{~g} / \mathrm{L}$

Sodium sulphate $=2.8 \mathrm{~g} / \mathrm{L}$

$\mathrm{COD}=1.9 \mathrm{~g} \mathrm{O}_{2} / \mathrm{L}$

Phosphorus $=0.009 \mathrm{~g} / \mathrm{L}$

Nitrogen $=0.004 \mathrm{~g} / \mathrm{L}$

Sodium sulphate $=3.8 \mathrm{~g} / \mathrm{L}$

Supplier

In Portugal, near the western beginning of the IPB, is located one of the world's major industrial complexes producing paper pulp and paper (Navigator Company, formerly -.. Portucel Soporcel), which produces large amounts of wastewaters.

Biological sulphate reduction was successfully tested to treat the primary clarifier effluent from a paper mill with a simultaneous high-rate removal of sulphate and COD (Chen and Horan 1998), which suggests the presence of sources of carbon /electron donors suitable for SRB in paper .... industries wastewaters.

\section{Dissolved organic matter in raw wastewater or}

biologically treated wastewater consists of

different molecular weight (MW) fractions

WWTP lagoon system in Mina de São Domingos, Portugal:

ranging from low MW substances (e.g. amino

acids, carboxylic acids, alcohols, aldehydes,

etc.) to high MW compounds such as humic

substances, polysaccharides, and proteins.

- Municipal wastewater from the first
lagoon with dissolved and suspended
solids

$\mathrm{COD}=0.55 \pm 0.28 \mathrm{~g} \mathrm{O}_{2} / \mathrm{L}$

Oils and fats $=0.041 \pm 0.018 \mathrm{~g} / \mathrm{L}$

Phosphorus $=0.011 \pm 0.004 \mathrm{~g} / \mathrm{L}$

Nitrogen $=0.102 \pm 0.046 \mathrm{~g} / \mathrm{L}$
Aiming to encourage the implementation of

(e.g. Raunkjaer et al. 1994. SRB biological processes to treat the AMD 4; in small villages, such as Mina de São Domingos.

Previous works have reported that municipal wastewater can be used as source of carbon/electron donors for SRB (e.g. Costa and Duarte 2005), thus having potential to sustain SRB biological processes in remote locals.
Pine nuts industry in Pedrajas de San Sebastian,

Spain:

Cellulose $=33.3 \%$

Hemicelulose $=32.1 \%$

- Pine nut shells
Lignin $=32.4 \%$

Extractives (essential oils, resins, etc. $)=1.7 \%$

Nitrogen $=0.4 \%$
In Europe, Portugal and Spain are the main producers of pine nuts and this activity generates large amounts of pine nut shells and pine cones, which by their availability have potential to be an important source of cellulosic compounds.

Other types of cellulosic compounds have 
Cellulose $=43.8 \%$

Hemicelulose $=27.2 \%$

Kalson lignin $=21.5 \%$

- Pine cone fragments
(Rambabu et al. 2016)

Acid soluble lignin $=0.6 \%$

Extractives (essential oils, resins, etc.) $=5.2 \%$

Nitrogen $=0.27 \%$

(Almendros et al. 2015) already been reported as suitable sources of carbon/electron donors for SRB (e.g. wood chips and sawdust (Choudhary and Sheoran 2011; Zhang and Wang 2014)). 
Table 2

\begin{tabular}{|c|c|c|c|c|c|c|}
\hline Substrates and their origins & pH & $\begin{array}{c}\mathrm{COD} \\
\left(\mathrm{g} \mathrm{O}_{2} / \mathrm{L}\right)\end{array}$ & $\begin{array}{l}{\left[\mathrm{SO}_{4}{ }^{2-}\right]} \\
(\mathrm{g} / \mathrm{L})\end{array}$ & $\begin{array}{c}{[\mathbf{N}]} \\
(\mathrm{g} \mathrm{N} / \mathrm{L})\end{array}$ & $\begin{array}{c}{[\mathbf{P}]} \\
(\mathrm{g} \mathbf{P} / \mathbf{L})\end{array}$ & $\begin{array}{c}\text { Estimated dose } \\
\text { for } \mathrm{COD} /\left[\mathrm{SO}_{4}{ }^{2}\right]= \\
1.5^{\mathrm{a}} \\
(\%)^{\mathrm{b}}\end{array}$ \\
\hline \multicolumn{7}{|l|}{ Candy factory: } \\
\hline $\begin{array}{l}\text { - Sugared water (from an homogenization } \\
\text { tank) }\end{array}$ & 4.44 & 14.8 & 0.05 & 0.29 & 0.12 & 14.73 \\
\hline \multicolumn{7}{|l|}{ Sugar processing factory from beetroot: } \\
\hline - Beetroot molasses & 7.64 & 1192 & 2.3 & 51.1 & 17.3 & 0.21 \\
\hline - Water from washing the beetroots & 7.31 & 1.1 & 0.011 & 0.38 & $<0.002 *$ & 70.47 \\
\hline - Carbocal ${ }^{\mathrm{c}}$ & 9.58 & 1.1 & 0.096 & $<0.01 *$ & $<0.002 *$ & 72.36 \\
\hline \multicolumn{7}{|l|}{ Olive oil Press: } \\
\hline - Olive mill wastewater not decanted & 4.48 & 39.9 & 0.46 & 2.4 & 0.18 & 6.11 \\
\hline - Olive mill wastewater decanted & 4.73 & 44.8 & 0.53 & 2.2 & 0.13 & 5.48 \\
\hline \multicolumn{7}{|l|}{ Orange juice factory: } \\
\hline $\begin{array}{l}\text { - Orange molasses with conservative } \\
\text { (CetoSTAT® TMR) }\end{array}$ & 4.20 & 724.0 & 0.68 & 43.9 & 0.17 & 0.35 \\
\hline - Orange molasses without conservative & 5.35 & 707.0 & 0.98 & 21.4 & 0.40 & 0.36 \\
\hline - Liquor extracted from orange peels & 4.03 & 150.4 & 0.26 & 3.9 & 2.6 & 1.67 \\
\hline - Orange peel fragments ${ }^{c}$ & 5.19 & 7.0 & 0.027 & 0.053 & 0.18 & 26.86 \\
\hline - Water from washing the equipments & 6.46 & 4.4 & 0.41 & 0.29 & $<0.002^{*}$ & 40.00 \\
\hline \multicolumn{7}{|l|}{ Paper pulp and paper factories: } \\
\hline - Pulp factory alkaline wastewater & 9.35 & 1.6 & 0.82 & $<0.01 *$ & 0.0034 & 88.97 \\
\hline - Pulp factory neutral wastewater & 7.80 & 1.0 & 0.82 & $<0.01 *$ & 0.0095 & I \\
\hline - Paper factory wastewater & 7.31 & 0.33 & 0.154 & $<0.01 *$ & $<0.002 *$ & 96.34 \\
\hline - Final mixed treated effluent & 7.49 & 0.19 & 0.56 & $<0.01 *$ & 0.0034 & $\mathrm{I}$ \\
\hline \multicolumn{7}{|l|}{ WWTP at "Mina de São Domingos": } \\
\hline - Municipal waste water from the first lagoon & 7.65 & 0.46 & 0.060 & 0.099 & 0.0088 & 87.27 \\
\hline \multicolumn{7}{|l|}{ Pine nuts industry: } \\
\hline - Pine nut shells ${ }^{c}$ & 5.88 & 0.30 & 0.016 & $<0.01 *$ & $<0.002 *$ & 90.07 \\
\hline - Pine cone fragments ${ }^{\mathrm{c}}$ & 5.95 & 0.41 & 0.018 & $<0.01 *$ & 0.010 & 86.94 \\
\hline \multicolumn{7}{|c|}{$\begin{array}{l}\text { a) Calculated as described in materials and methods for dilutions in Postgate } \mathrm{B}\left(1.7 \mathrm{~g} / \mathrm{L} \mathrm{SO}_{4}^{2-}\right) \text { without lactate } \\
\text { (assuming its COD is zero). } \\
\text { b) v/v for liquids and w/v for substrates. } \\
\text { c) To characterize solid substrates, measurements were made in samples after homogenization of } 10 \% \text { (w/v) substrate } \\
\text { in water and } 24 \text { hours lixiviation without agitation. } \\
* \text { Limit of detection (LOD) }\end{array}$} \\
\hline
\end{tabular}


Table 3

\begin{tabular}{|c|c|c|c|c|c|c|c|c|c|c|c|c|c|c|c|c|c|}
\hline \multirow{3}{*}{$\begin{array}{l}\text { Test } \\
\mathbf{N}^{\text {er }}\end{array}$} & \multirow{3}{*}{ Substrates } & \multirow{3}{*}{$\begin{array}{l}\text { Tested } \\
\text { dose }^{\mathrm{a}} \\
(\%)\end{array}$} & \multicolumn{5}{|c|}{ Initial Values } & \multicolumn{10}{|c|}{ Values achieved } \\
\hline & & & \multirow{2}{*}{$\mathrm{pH}$} & \multirow{2}{*}{$\begin{array}{c}\text { Redox } \\
\text { Potent. } \\
\text { Eh } \\
(\mathrm{mV})\end{array}$} & \multirow{2}{*}{$\begin{array}{l}\mathrm{COD} \\
\left(\mathrm{mgO}_{2}\right. \\
/ \mathrm{L})\end{array}$} & \multirow{2}{*}{$\begin{array}{l}{\left[\mathrm{SO}_{4}{ }^{2-}\right]} \\
(\mathrm{mg} / \mathrm{L})\end{array}$} & \multirow{2}{*}{$\begin{array}{l}\mathrm{COD} / \\
{\left[\mathrm{SO}_{4}^{2-}\right]} \\
\text { ratio }\end{array}$} & \multicolumn{2}{|c|}{$\begin{array}{c}\text { Redox Potent. } \\
\text { Eh } \\
(\mathrm{mV})\end{array}$} & \multicolumn{2}{|c|}{ pH } & \multicolumn{2}{|c|}{$\begin{array}{c}\text { Maxim. } \\
{\left[\mathbf{S}^{2}\right]} \\
(\mathbf{m g} / \mathbf{L})\end{array}$} & \multicolumn{2}{|c|}{$\begin{array}{c}\text { Maxim. } \mathrm{SO}_{4}{ }^{2-} \\
\text { removal } \\
(\%)\end{array}$} & \multirow{2}{*}{$\begin{array}{l}\text { Time to } \\
\text { reach } \\
\text { maxim. } \\
\mathrm{SO}_{4}^{2-} \\
\text { removal } \\
\text { (days) }\end{array}$} & \multirow{2}{*}{$\begin{array}{l}\text { Time to } \\
\text { reach } \\
90 \% \text { of } \\
\text { maxim. } \\
\mathrm{SO}_{4}^{2-} \\
\text { removal } \\
\text { (days) }\end{array}$} \\
\hline & & & & & & & & Aver. & $\mathrm{MAD}^{\mathrm{b}}$ & Aver. & $\mathrm{MAD}^{\mathrm{b}}$ & Aver. & $\mathrm{MAD}^{\mathrm{b}}$ & Aver. & $\mathrm{MAD}^{\mathrm{b}}$ & & \\
\hline & \multicolumn{17}{|l|}{ Candy factory: } \\
\hline 1 & \multirow{3}{*}{ Sugared water (from an homogenization tank) } & 2 & 6.44 & -177 & 1265 & 1451 & 0.87 & -92 & 56 & 6.89 & 0.03 & 15 & 1 & 24 & 0 & 17 & 17 \\
\hline 2 & & 10 & 6.67 & -79 & 2640 & 1338 & 1.97 & -199 & 7 & 5.92 & 0.02 & 65 & 3 & 39 & 1 & 17 & 17 \\
\hline 3 & & 20 & 6.25 & -50 & 3488 & 1200 & 2.91 & -125 & 31 & 5.15 & 0.17 & 39 & 20 & 20 & 9 & 29 & 17 \\
\hline 4 & \multirow{3}{*}{ Sugared water (from an homogenization tank) + calcite $^{\mathrm{c}}$} & 5 & 7.29 & -48 & 1967 & 1266 & 1.55 & -348 & 3 & 7.02 & 0.00 & 33 & 2 & 47 & 4 & 26 & 26 \\
\hline 5 & & 10 & 7.25 & -68 & 2640 & 1279 & 2.06 & -350 & 2 & 6.83 & 0.02 & 79 & 2 & 57 & 1 & 26 & 14 \\
\hline \multirow[t]{2}{*}{6} & & 20 & 7.15 & -53 & 3488 & 1125 & 3.10 & -314 & 38 & 6.79 & 0.02 & 142 & 11 & 79 & 4 & 40 & 14 \\
\hline & Sugar processing factory from beetroot: & & & & & & & & & & & & & & & & \\
\hline 7 & \multirow{4}{*}{ Beetroot molasses } & 0.25 & 6.69 & 86 & 4035 & 1523 & 2.65 & -52 & 7 & 5.13 & 0.00 & 9 & 0 & 5 & 0 & 17 & 17 \\
\hline 8 & & 0.5 & 6.68 & 29 & 6580 & 1550 & 4.25 & 13 & 14 & 4.29 & 0.00 & 4 & 1 & 5 & 1 & 17 & 17 \\
\hline 9 & & 1.33 & 6.86 & -71 & 13619 & 1559 & 8.74 & 84 & 1 & 4.25 & 0.01 & 2 & 1 & 6 & 2 & 17 & 17 \\
\hline 10 & & 10 & 7.41 & -177 & 122000 & 1910 & 63.87 & -29 & 1 & 5.18 & 0.05 & 3 & 2 & 3 & 0 & 17 & 17 \\
\hline 11 & \multirow{4}{*}{ Beetroot molasses + calcite $^{\mathrm{c}}$} & 0.25 & 7.46 & 86 & 4035 & 1273 & 3.17 & -344 & 172 & 6.96 & 0.08 & 138 & 14 & 71 & 2 & 26 & 14 \\
\hline 12 & & 0.5 & 7.36 & 29 & 6580 & 1348 & 4.88 & -301 & 61 & 7.00 & 0.08 & 192 & 24 & 85 & 6 & 40 & 26 \\
\hline 13 & & 1 & 7.37 & -71 & 11920 & 1398 & 8.53 & -262 & 57 & 6.51 & 0.08 & 46 & 3 & 30 & 3 & 40 & 40 \\
\hline 14 & & 2 & 7.31 & -165 & 23840 & 1493 & 15.97 & -114 & 25 & 6.46 & 0.00 & 4 & 1 & -7 & 4 & 40 & 40 \\
\hline 15 & \multirow{2}{*}{ Water from washing the beetroots } & 10 & 7.42 & -286 & 954 & 1238 & 0.77 & -361 & 7 & 7.67 & 0.03 & 27 & 3 & 17 & 1 & 29 & 29 \\
\hline 16 & & 20 & 7.51 & -285 & 886 & 1120 & 0.79 & -359 & 14 & 7.42 & 0.01 & 74 & 1 & 31 & 7 & 49 & 49 \\
\hline 17 & \multirow{3}{*}{ Carbocal $\AA^{\mathrm{d}}$} & 0.1 & 7.36 & -176 & 1079 & 1476 & 0.73 & -58 & 6 & 7.25 & 0.03 & 7 & 0 & 18 & 0 & 17 & 17 \\
\hline 18 & & 1 & 8.07 & -229 & 1240 & 1552 & 0.80 & -49 & 9 & 7.85 & 0.02 & 1 & 1 & 21 & 1 & 29 & 17 \\
\hline 19 & & 10 & 8.14 & -197 & 1544 & 1589 & 0.97 & -418 & 1 & 7.85 & 0.00 & 195 & 2 & 53 & 1 & 40 & 26 \\
\hline & \multicolumn{17}{|l|}{ Olive oil press: } \\
\hline 20 & & 4 & 7.34 & 60 & 461 & 1062 & 0.43 & -343 & 10 & 7.40 & 0.04 & 44 & 1 & 55 & 14 & 28 & 28 \\
\hline 21 & Olive mill wastewater (OMW) not decanted + calcite $^{c}$ & 7 & 7.20 & 60 & 695 & 1044 & 0.67 & -352 & 6 & 7.26 & 0.04 & 59 & 7 & 69 & 27 & 28 & 28 \\
\hline 22 & & 20 & 7.07 & 55 & 1142 & 1056 & 1.08 & -332 & 50 & 7.28 & 0.06 & 149 & 49 & 95 & 2 & 28 & 28 \\
\hline 23 & & 3.5 & 7.45 & 63 & 428 & 1053 & 0.41 & -295 & 53 & 7.35 & 0.01 & 45 & 0 & 42 & 2 & 28 & 28 \\
\hline 24 & Olive mill wastewater (OMW) decanted + calcite $^{c}$ & 6 & 7.43 & 57 & 627 & 998 & 0.63 & -330 & 28 & 7.47 & 0.11 & 52 & 9 & 64 & 8 & 28 & 28 \\
\hline 25 & & 20 & 7.00 & 59 & 1357 & 835 & 1.63 & -325 & 38 & 7.24 & 0.04 & 226 & 39 & 93 & 2 & 28 & 28 \\
\hline
\end{tabular}


Orange juice factory:

\begin{tabular}{|c|c|c|c|c|c|c|c|c|c|c|c|c|c|c|c|c|c|}
\hline 26 & \multirow{3}{*}{$\begin{array}{l}\text { Orange molasses with conservative (CetoSTAT } ® \text { TMR) } \\
+ \text { calcite }^{c}\end{array}$} & 0.25 & 7.58 & 23 & 384 & 932 & 0.41 & $\begin{array}{l}-304 \\
\end{array}$ & 59 & 7.01 & 0.01 & 48 & 2 & 22 & 1 & 28 & 28 \\
\hline 27 & & 0.5 & 7.41 & 31 & 760 & 844 & 0.90 & -298 & 71 & 6.83 & 0.01 & 36 & 9 & 49 & 1 & 42 & 42 \\
\hline 28 & & 1 & 7.37 & 80 & 1359 & 1037 & 1.31 & -225 & 31 & 6.39 & 0.06 & 56 & 37 & 18 & 15 & 42 & 42 \\
\hline 29 & \multirow{3}{*}{ Orange molasses without conservative + calcite $^{c}$} & 0.25 & 7.63 & 53 & 448 & 1202 & 0.37 & -303 & 57 & 6.95 & 0.00 & 49 & 10 & 51 & 3 & 28 & 28 \\
\hline 30 & & 0.5 & 7.57 & 64 & 741 & 1222 & 0.61 & -344 & 1 & 6.84 & 0.08 & 106 & 12 & 70 & 3 & 28 & 28 \\
\hline 31 & & 1 & 7.30 & 57 & 1062 & 1190 & 0.89 & -233 & 13 & 6.42 & 0.04 & 83 & 14 & 46 & 0 & 28 & 21 \\
\hline 32 & \multirow{3}{*}{$\begin{array}{l}\text { Liquor extracted from orange peels } \\
+ \text { calcite }^{\mathrm{c}}\end{array}$} & 1.25 & 7.39 & 26 & 577 & 1254 & 0.46 & -225 & 53 & 6.85 & 0.09 & 21 & 27 & 37 & 1 & 28 & 21 \\
\hline 33 & & 2.5 & 7.26 & 26 & 877 & 1256 & 0.70 & -202 & 52 & 6.50 & 0.11 & 39 & 38 & 34 & 13 & 28 & 21 \\
\hline 34 & & 10 & 6.52 & 60 & 3475 & 1093 & 3.18 & -112 & 7 & 5.94 & 0.08 & 5 & 0 & 11 & 0 & 14 & 7 \\
\hline 35 & \multirow{3}{*}{ Orange peel fragments ${ }^{d}+$ calcite $^{c}$} & 1 & 7.31 & 42 & 963.5 & 1138.5 & 0.85 & $\begin{array}{l}-363 \\
\end{array}$ & 1 & 7.26 & 0.08 & 106 & 45 & 91 & 9 & 121 & 121 \\
\hline 36 & & 4 & 7.33 & 59 & 1146 & 1224 & 0.94 & -258 & 22 & 6.21 & 0.04 & 95 & 8 & 99 & 1 & 121 & 121 \\
\hline 37 & & 8 & 7.02 & 35 & 1320 & 1164 & 1.13 & -110 & 11 & 6.10 & 0.17 & 2 & 1 & 6 & 3 & 28 & 28 \\
\hline \multirow[t]{2}{*}{38} & Water from washing the equipments + calcite $^{\mathrm{c}}$ & 20 & 7.37 & 81 & 349 & 935 & 0.37 & -314 & 67 & 7.30 & 0.08 & 49 & 16 & 53 & 12 & 21 & 21 \\
\hline & \multicolumn{17}{|l|}{ Paper pulp and paper factories: } \\
\hline 39 & Pulp factory alkaline wastewater + calcite $^{c}$ & 20 & 7.59 & 70 & 221 & 1001 & 0.22 & -226 & 8 & 7.41 & 0.01 & 17 & 1 & 25 & 6 & 14 & 14 \\
\hline 40 & Pulp factory neutral wastewater + calcite $^{c}$ & 20 & 7.69 & 67 & 250 & 870 & 0.29 & -93 & 23 & 7.43 & 0.04 & 4 & 1 & 11 & 5 & 21 & 21 \\
\hline 41 & Paper factory wastewater + calcite $^{c}$ & 20 & 7.55 & 53 & 212 & 1111 & 0.19 & -209 & 181 & 7.29 & 0.01 & 29 & 2 & 29 & 2 & 14 & 14 \\
\hline \multirow[t]{2}{*}{42} & Final mixed treated effluent + calcite $^{\mathrm{c}}$ & 20 & 7.69 & 65 & 223 & 933 & 0.24 & -49 & 15 & 7.52 & 0.01 & 23 & 9 & 27 & 2 & 28 & 28 \\
\hline & WWTP at "Mina de São Domingos": & & & & & & & & & & & & & & & & \\
\hline 43 & \multirow{2}{*}{ Municipal waste water from the first lagoon + calcite $^{c}$} & 20 & 7.23 & 48 & 743 & 830 & 0.90 & -251 & 175 & 7.42 & 0.23 & 218 & 16 & 82 & 2 & 28 & 28 \\
\hline \multirow[t]{2}{*}{44} & & 50 & 7.44 & 44 & 1099 & 469 & 2.34 & -197 & 133 & 7.30 & 0.27 & 153 & 60 & 81 & 18 & 28 & 28 \\
\hline & Pine nuts industry: & & & & & & & & & & & & & & & & \\
\hline 45 & Pine nut shells ${ }^{d}+$ calcite $^{c}$ & 10 & 7.14 & 27 & 877 & 951.5 & 0.92 & -28 & 13 & 7.41 & 0.01 & 7 & 2 & 99 & 0 & 121 & 121 \\
\hline \multirow[t]{2}{*}{46} & Pine cone fragments ${ }^{\mathrm{d}}+$ calcite $^{\mathrm{c}}$ & 10 & 7.07 & 41 & 911.5 & 1007.5 & 0.90 & -124 & 36 & 7.19 & 0.11 & 18 & 1 & 97 & 0 & 121 & 121 \\
\hline & Controls: & & & & & & & & & & & & & & & & \\
\hline 47 & Positive 1: Postgate B & - & 6.63 & 184 & 4112 & 1462 & 2.81 & -397 & 1 & 7.23 & 0.02 & 304 & 13 & 92 & 0 & 14 & 7 \\
\hline 48 & Positive 2: Postgate $\mathrm{B}+$ calcite $^{\mathrm{c}}$ & - & 7.07 & 183 & 4112 & 1664 & 2.47 & -399 & 1 & 7.27 & 0.03 & 259 & 9 & 87 & 0 & 14 & 7 \\
\hline 49 & Negative: Postgate $B$ without lactate + calcite $^{c}$ & - & 7.33 & 33 & 876 & 1089.5 & 0.80 & -202 & 59 & 7.57 & 0.10 & 9 & 5 & 25 & 10 & 28 & 28 \\
\hline
\end{tabular}

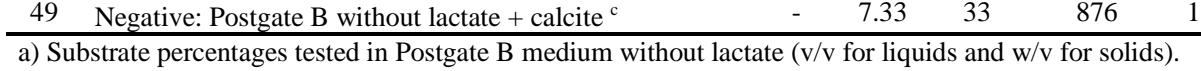

b) Aver. = Average; MAD = mean absolute deviation (the average distance between each data value and the mean - in this case, with $\mathrm{n}=2$, it is the real distance to individual data points).

c) $10 \%(w / v)$ of calcite tailings powder.

d) In the cultures with the solid substrates Carbocal@, orange peel fragments, pine nut shells and pine cone fragments, the parameters were measured in the aqueous phase of medium 24 hours after mixing the substrates. 


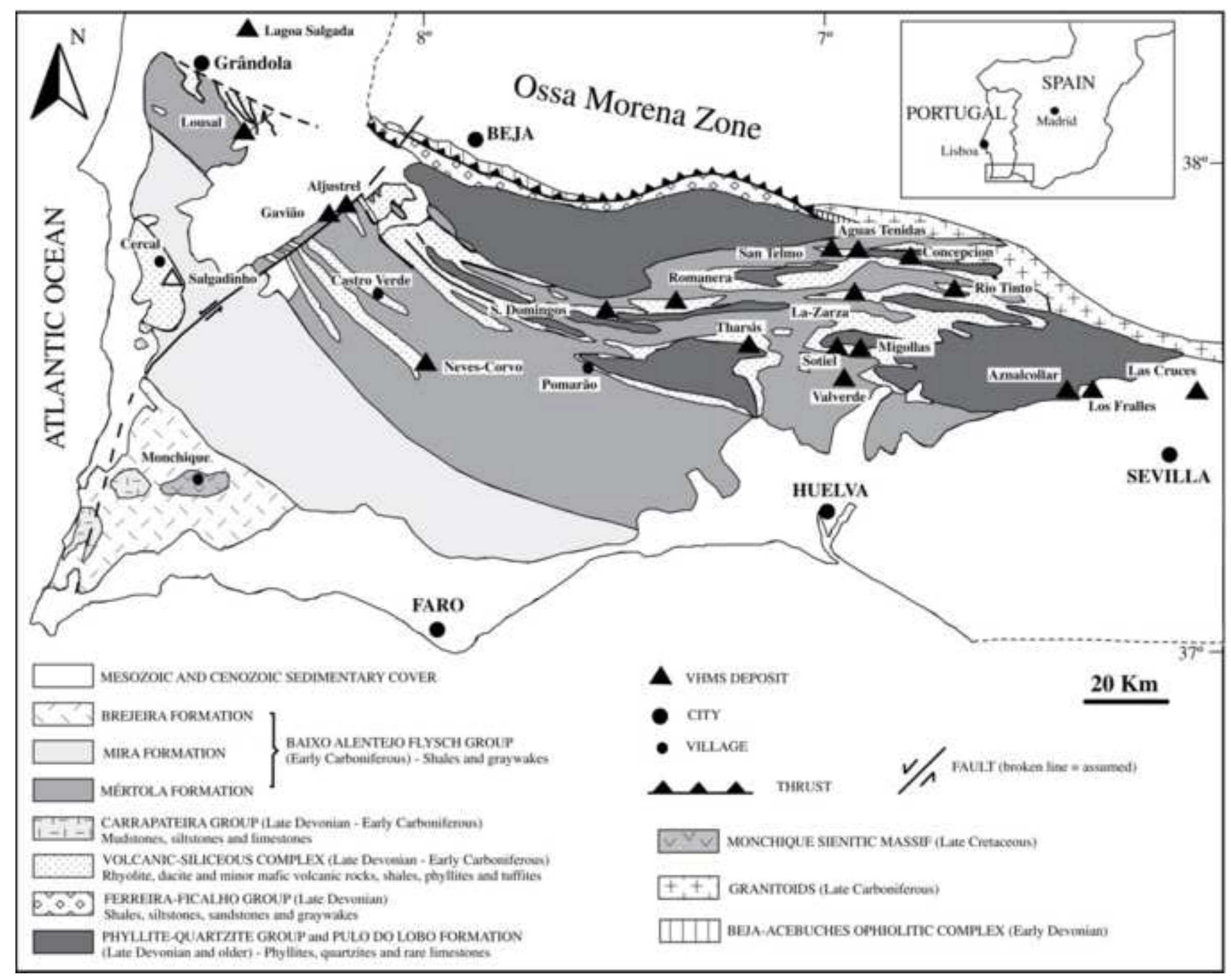




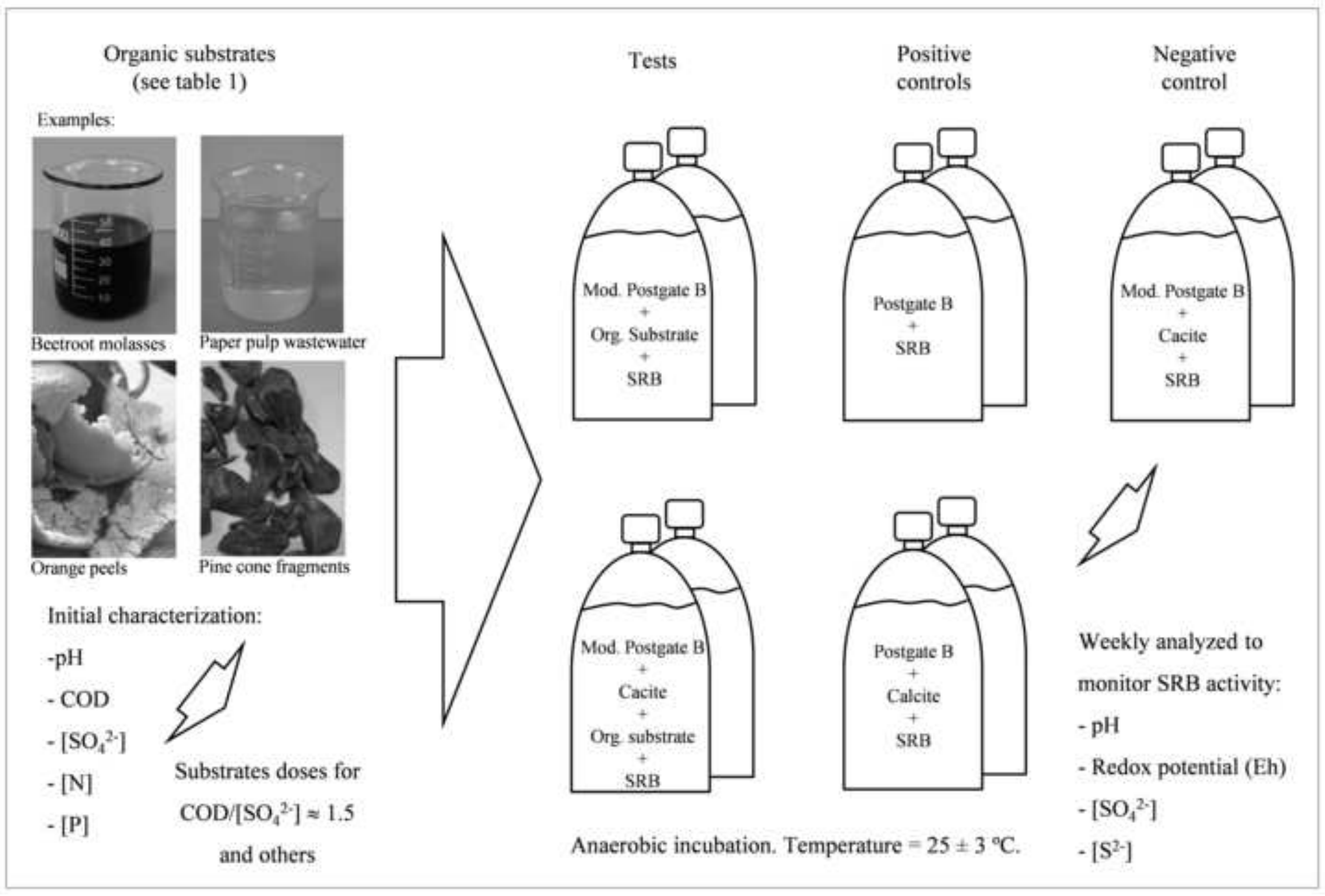

Organic substrates

(see table 1)

Examples:

Bectroot molasses

Initial characterization:

$-\mathrm{pH}$

- COD

$\left[\mathrm{SO}_{4}^{2-}\right.$

Substrates doses for

and others controls

$-\left[\mathrm{S}^{2}-\right]$ 

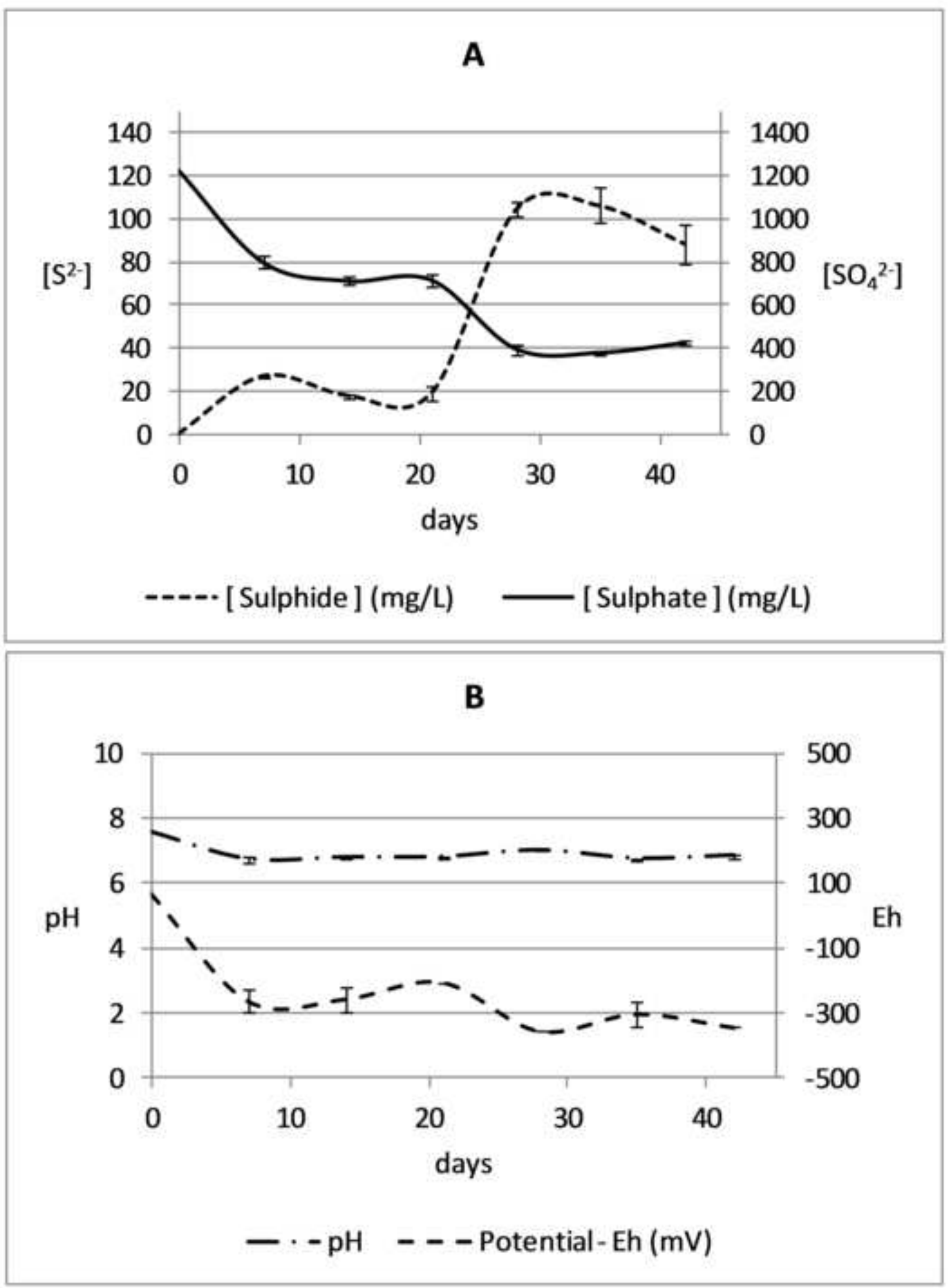
Fig. 3

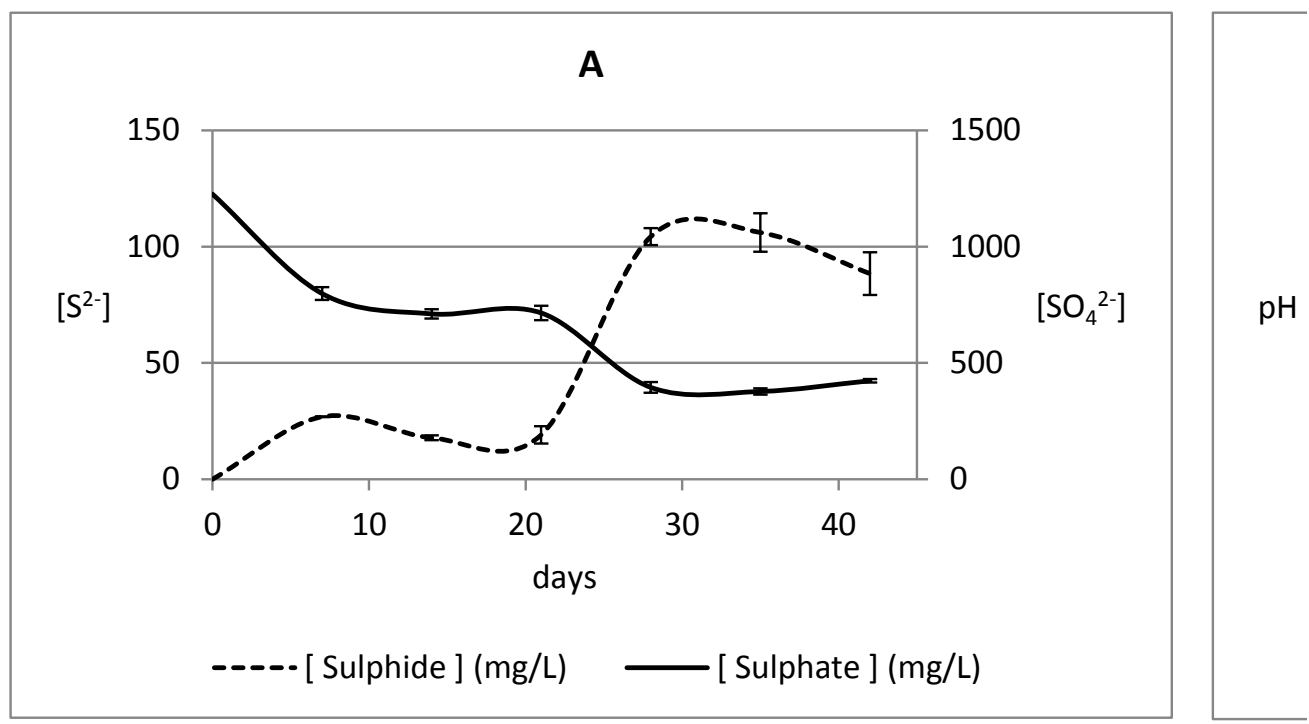

\begin{tabular}{|c|c|c|c|}
\hline & & date & $2 / 11$ \\
\hline & Experiment & samples & initial $r$ \\
\hline Test N.er & Substrates & Days & \\
\hline & & Potential - Eh (mV) & \\
\hline & Orange molasses without & $\mathrm{pH}$ & \\
\hline ט & & [ Sulphide ] (mg/L) & \\
\hline & & [ Sulphate ] (mg/L) & \\
\hline
\end{tabular}




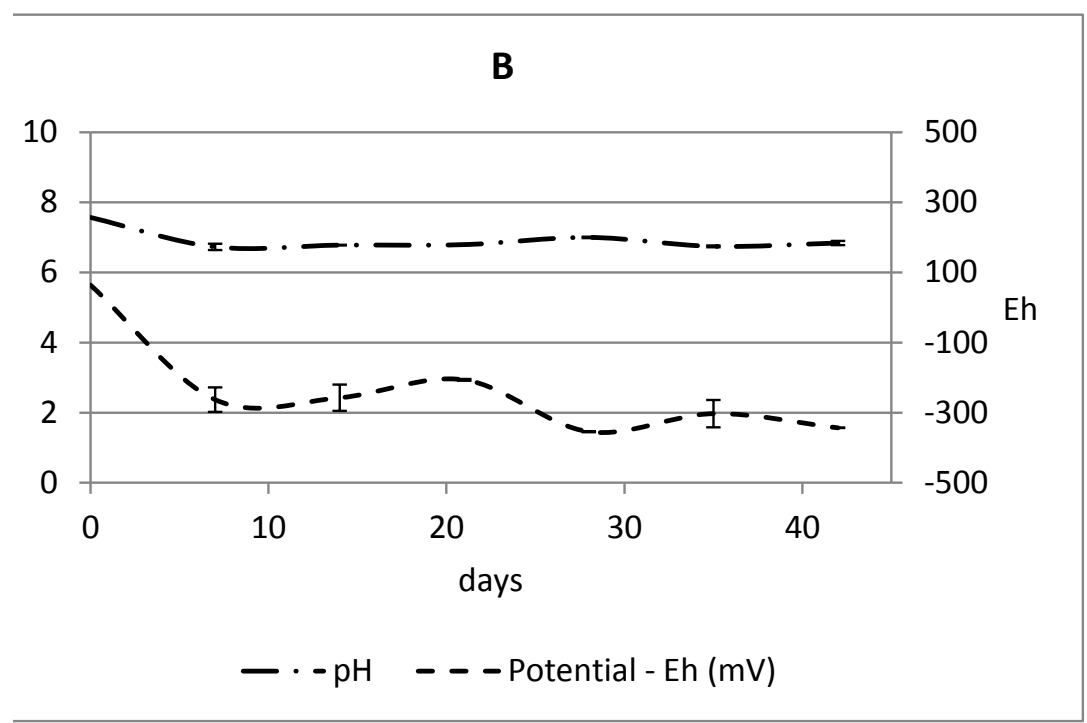

\begin{tabular}{|c|c|c|c|c|c|c|c|c|}
\hline \multirow{3}{*}{12015} & \multicolumn{4}{|c|}{$2 / 19 / 2015$} & \multicolumn{4}{|c|}{$2 / 26 / 2015$} \\
\hline & \multicolumn{2}{|c|}{ replicates } & \multirow{2}{*}{ average } & \multirow{2}{*}{ MAS } & \multicolumn{2}{|c|}{ replicates } & \multirow{2}{*}{ average } & \multirow{2}{*}{ MAS } \\
\hline & 1 & 2 & & & 1 & 2 & & \\
\hline 0 & & & 7 & & & & 14 & \\
\hline 64 & -228 & -298 & -263.00 & 35.00 & -295 & -220 & -257.50 & 37.50 \\
\hline 7.57 & 6.82 & 6.64 & 6.73 & 0.09 & 6.77 & 6.79 & 6.78 & 0.01 \\
\hline 0 & 27.03 & 26.71 & 26.87 & 0.16 & 16.81 & 18.88 & 17.85 & 1.04 \\
\hline 1226 & 771 & 826 & 798.50 & 27.50 & 691 & 731 & 711.00 & 20.00 \\
\hline
\end{tabular}




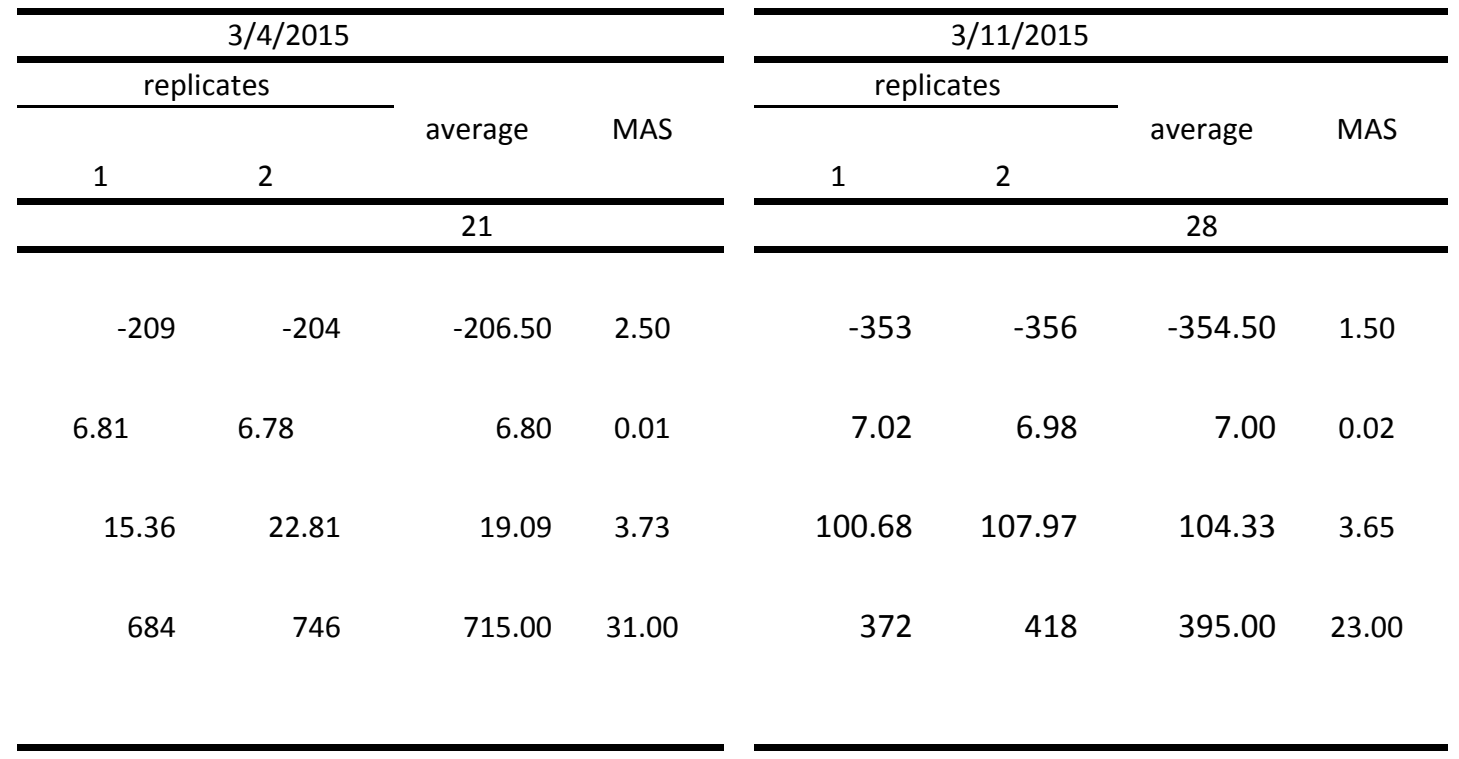




\begin{tabular}{|c|c|c|c|c|c|c|c|}
\hline \multicolumn{4}{|c|}{$3 / 18 / 2015$} & \multicolumn{4}{|c|}{ 25-03--2015 } \\
\hline \multicolumn{2}{|c|}{ replicates } & \multirow{3}{*}{ average } & \multirow{3}{*}{ MAS } & \multicolumn{2}{|c|}{ replicates } & \multirow{3}{*}{ average } & \multirow{3}{*}{ MAS } \\
\hline & & & & & & & \\
\hline 1 & 2 & & & 1 & 2 & & \\
\hline & & \multicolumn{2}{|l|}{35} & & & \multicolumn{2}{|l|}{42} \\
\hline-342 & -264 & -303.00 & 39.00 & -343 & -344 & -343.50 & 0.50 \\
\hline 6.72 & 6.77 & 6.75 & 0.02 & 6.9 & 6.78 & 6.84 & 0.06 \\
\hline 114.36 & 97.82 & 106.09 & 8.27 & 79.24 & 97.6 & 88.42 & 9.18 \\
\hline 364 & 391 & 377.50 & 13.50 & 416 & 431 & 423.50 & 7.50 \\
\hline
\end{tabular}


Click here to access/download Supplementary Material Suplemmentary material.pdf 